NBSIR 85-3166

\title{
Studies of Porous Metal Coated Surgical Implants
}

A. C. Fraker' ${ }^{1}$ A. W. Ruff', A. C. Van Orden', H. Hahn², A. J. Bailey' and C. D. Olson'

'U.S. DEPARTMENT OF COMMERCE

National Bureau of Standards

Gaithersburg, MD 20899

June 1985

Prepared for:

FDA Contract 224795023

Q)

100

.456

$85-3166$ 1985 



\section{STUDIES OF POROUS METAL COATED SURGICAL IMPLANTS}

A. C. Fraker', A. W. Ruff', A. C. Van Orden', H. Hahn², A. J. Bailey' and C. D. Olson'

'U.S. DEPARTMENT OF COMMERCE

National Bureau of Standards

Gaithersburg, MD 20899

${ }^{2}$ Artech Corporation

Falls Church, VA 22042

June 1985

Prepared for:

FDA Contract 224795023

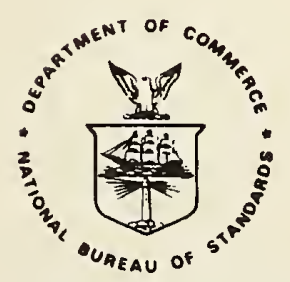

U.S. DEPARTMENT OF COMMERCE, Malcolm Baldrige, Secretary NATIONAL BUREAU OF STANDARDS, Ernest Ambler, Director 



\section{Contents}

\section{Page}

I. Brief Literature Review of Metal Porous Coatings 1 Anna C. Fraker

II. Corrosion Behavior of Sintered Porous Coated $\mathrm{Co}-\mathrm{Cr}-\mathrm{MO}$ Surgical Implant Metal

Ann C. Van Orden and Anna C. Fraker

III. Corrosion-Fatigue Behavior of ArC Plasma Sprayed Ti or Ti-6AT-4V Coatings on $\mathrm{Ti}-6 \mathrm{AT}-4 \mathrm{~V}$ Substrates Anna C. Fraker, Henry Hahn, Alison J. Bailey and Craig

D. Olson

IV. Acknowledgements

Note: The use of materials and equipment in these studies does not imply endorsement by NBS. 



\section{Part I}

Brief Literature Review of Metal Porous Coatings 



\section{Porous Metal Surgical Implants}

\section{Introduction}

This report is on the topic of porous metal coated metal surgical implants which are in use or clinical study. This is a rapidly developing technology, and the introduction of additional types of porous coated metals or metal combinations can be expected. Porous coated implants may be rough surfaces, a single layer of spheres, fibers, etc., or porous coatings may consist of several layers. The pore size probably should not be less than $100 u m$, and the porosity should be interconnecting. The most used porous coatings at present include those which are sintered on to the substrate ${ }^{1}$, those sintered together and mechanically held to the substrate ${ }^{2}$ and coatings applied by the arc plasma spraying process ${ }^{3}$. These coatings can be subject to phase changes due to sintering, oxidation and contamination. Application of the porous coating should not affect the mechanical strength of the prosthesis. Descriptions of these porous materials should include chemical compositions of substrate and porous coating, mechanical properties and all processing parameters and temperatures involved in the production of the prosthesis. This review will present some background information relating to the need for improved orthopedic materials, some comments on internal fixation of devices, and an overview of porous metals used in orthopedic devices. 
Background Information Relating to Need

Two major factors dictate the need for more reliable implants: the average life span has increased and the number of younger people receiving bone implants has increased. The necessity of the continued development of surgical implant materials can be illustrated with the following statistics. In 1976, approximately 120,000 total joints were implanted in the United States. This included 80,000 hips, 30,000 knees, 8,000 fingers, and 2,000 other joints.4 An Arthur D. Little report 5 in 1982 gave annual figures for total hips of 100,000, total knees of 50,000 and other joints of 12,000 .

The need for increased studies of various aspects of total hip replacement was highlighted by the National Institutes of Health Consensus Development Conference which was held March 1-3, 1982 at the Masur Auditorium on the NIH campus. 6 At this meeting it was stated that approximately 100,000 total hip replacements are made in the United States each year. Each total hip repacement costs around $\$ 9,500.7$ Any complications or revisions can result in multiples of this figure. Earlier estimates of the patient cost for failed implants were 100 million dollars per year. 6 Since many of the patients receiving total joints are over 65, much of this cost is borne directly by the Federal Government through Medicare. The increased pain and problems for the patient are beyond quantification Nevertheless, the prognosis for total hip surgery is good, and a conservative figure for the success rate is 90 percent. The longer term success rate going beyond 10 years is less well known.

Studies of groups of patients have given figures of 12 percent for prosthesis loosening over a period of 8 years. 8 These data were reported from The Hip Society by Richard J. Johnston, M.D., who emphasized the success of the current mode of total hip surgery and predicted a 75 percent success rate at the end of 20 years. He cautioned against abandoning this successful procedure in favor of 
other procedures. Incidences of loosening after 10 years as indicated radiographically have been reported to be as high as 11.3 percent for the acetabular component and 29.9 percent for the femoral component. 9 This radiographic evidence did not indicate prosthesis failure or the need for revision but it did show that the prosthesis fixation was somewhat weakened. Indications for success in the total hip surgery are at such a high level that it seems feasible to consider that many more of the current failures can be eliminated. Failures associated with prosthesis loosening originate with the bone/bone-cement interface and with the metal/bone cement interface or a combination of both. Osteroarthritis is the major cause of joint replacement and mainly affects older people. Treatment of joint disease by replacement with artifical materials has become a highly successful mode of treatment for thousands of people suffering from disabling joint disease. Total joint replacement is a highly successful procedure, giving relief of pain and improved function to many people. In the next twenty years, the increased number of people coupled with the increasing mean age of the population could produce a potential patient population well above 180,000 persons. The cost, patient needs and the large number of joint replacements justify biomaterials development. 
Some Methods of Prosthesis Fixation

Surgical prosthesis fixation in the bone has been a subject of concern and study for many years. Prosthesis fixation has been accomplished by impaction of the prosthesis into the medullary cavity of the bone 2,10 and by mechanical means such as using screws 10,11,12. In the late 1950's, Charnley13 used poly (methyl methacrylate) cement, and this method of fixation is credited for the high success rate of joint prostheses since that time. However, each of these methods has problems and disadvantages which lead to the failure of the arthoplasty.

Devices impacted into the medullary cavity are/were held in place by compressive stress action. Stress concentrations can occur which result in overloading the implant material, and failure occurs. A small degree of motion can adversely affect bone growth A decrease in bone growth leads to loss of attachment and loosening of the device.

Mechanical internal fixation has been used as one of the methods of attachment of the acetabular portion of the toal hip prosthesis. Fixation with screws should not be used if indications are that loosening would be expected. This method has been used successfully 11 but less so than the cemented prosthesis.

Fixation with cement suffers from problems related to the nature of the cement14. Poly (methyl methacrylate) polymerizes in situ and secures the prosthesis in place. Heat develops during polymerization and may damage surrounding bone tissue. A toxic monomer may be released from the cement and this raises doubts about the use of cement from a biological viewpoint ${ }^{2}$. Some evidence indicates that delayed failures in cemented total hip prostheses may result from poor stability resulting from relative motion between the acrylic cement and the bone15,16. Other disadvantages include cement cracking due to voids, brittleness and loss of creep resistance. Improvements in fixation are being sought through means of boney ingrowth or cement attachment to a porous coated prosthesis. 
Overview of Porous Metals for Bony Ingrowth

Pore Size and Bone Growth. A comprehensive review of porous metal implants has been given by Spector 17 who discusses production methods, histology, mechanical properties and clinical trials. Spector noted that no adverse tissue growth into porous titanium, Co-Cr-Mo or 316L stainless steel had been observed and tissue ingrowth occurred in the pore size range of 100 um to 400 um. A Porocoat (Trade name of a DePuy product) brochure ${ }^{18}$ which contains seventy five references pertaining to porous metal implants, states that the best pore size range is 100 um to 300 um. Pilliar 19 , in a review dealing with porous ingrowth and processing of Co-Cr-Mo orthopedic implants, reports that ingrowth occurs in animals over a pore size range of 50 um to $400 \mathrm{um}$. Earlier work by Hulbert, et al.20 indicated tissue ingrowth into ceramic implants with pore sizes ranging from 45 um to 150 um and with more rapid growth in the larger pore size. A recent study 21 of the effect of pore size on peel strength of tissue used pore sizes ranging from 50 um to 200um. It was recommended on the basis of this study that the average pore size should not drop below 90 um and that pore sizes greater than 200 um might be better for ingrowth. Porous sintered Co-Cr-Mo substrates with porosity less than 100 um have exhibited loosening ${ }^{18}$.

Hungerford, et al, 22,23 indicated that the optimum pore size for implantation in humans would be $400 u m$ to $500 u m$ and reported that cementless knee prostheses with pore sizes of 400 um were successful. Nine knees were implanted in osteoarthritis patients and seven knees were implanted in rheumatoid arthritis patients. Scores showing increased joint usage of the osteoarthritis group ranged from 42 pre-operative to 92 post-operative and scores for the rheumatoid arthritis group ranged from 39 before to 86 after surgery. 
Healthy bone ingrowth for fixation of the prosthesis is needed as soon as possible following surgery. One way to increase this ingrowth is by electrical stimulation24. Prosthesis stabilization so that minimal or no movement occurs between the tissue and implant is required for bony ingrowth. Electrical stimulation is more effective in the early stages of bone growth and should be studied as a meansof assisting with initial stabilization. Published proceedings from a symposium on Bioelectric Effects on Bone and Cartilage 25 and from a symposium on Electrically Induced 0steogenesis 26 provide more details of research which has been conducted on this subject. Another technique which has been used to stabilize prostheses and to assist in bony ingrowth is the use of bioceramics in the form of calcium phosphates. Hydroxyapatite, $\mathrm{Ca}_{5}\left(\mathrm{PO}_{4}\right)_{3} \mathrm{OH}$, has been used as a filler material and as a coating 27 to stimulate bone growth. Hydroxyapatite increases the amount of bone growth during the first four weeks after surgery but after that the bone grows at the same rate with or without the hydroxyapatite. Whitlockite or beta tricalcium phosphate (TCP), $\mathrm{Ca}_{3}\left(\mathrm{PO}_{4}\right)_{2}$, is another material which is considered for treatment of bone lesions and as filler material28,29. TCP is biogradable and in particulate form can be incorporated into the bone but some adverse reactions at residual TCP sites were found in animal studies. TCP needs further testing and evaluation before it is put into use. Brown and Chow 30 have have developed a dicalcium phosphate-tetracalcium phosphate mixture, which when combined with water, sets by a process involving formation of hydroxyapatite. Its setting properties and its apparent non-resorbability should give it advantages over beta-TCP for some applications. More information on the fundamental chemistry of calcium phosphate and numerous references to their use may be found in a book entitled Bioceramics of Calcium Phosphates" edited by Klaas de Groot ${ }^{31}$.

It is unclear from reported studies ${ }^{18}$ whether smaller or larger pores result in a stronger bone/porous-surface interface bond. Most studies indicate increased 
strength with increasing pore size within a specified size range. Push-out test data show shear strength values ranging from $14.5 \mathrm{MPa}$ to $25.5 \mathrm{MPa} 32$. Predecki, et al.33 conducted studies of bone growth into screw type interfaces. Harris, et a $7^{34}$ used three screws to rigidly place porous coated (Co-Cr-Mo sintered spheres) acetabular components in canine hips. Bone growth covered 53 percent of the implant and no resorption was observed at the screws.

Some types of porous or irregular coatings are described in the following paragraphs, and many of these are in clinical trials today. The judet 35,36 hip prosthesis has an irregular cast surface with circular cavities for bone attachment, but it is nonporous. This method appears to be useful for fixation, but some stem fractures have occurred and more data on this system are needed 17 . Over 2000 cases cases have been reported with this type of fixation.

Another type of porous prosthesis is that developed by Lord 37 in which tiny spheres about $1 \mathrm{~mm}$ in diameter are cast on the surface about $0.5 \mathrm{~mm}$ apart. Bone attachment occurs with this nonporous surface. This coating is known as the madreporic porous coating.

Porous titanium implants have been successfully produced by a power metal sintering process to produce a void-metal composite ${ }^{38}$. Tests of this material in animals have shown healthy bone ingrowth with high shear strength at the bone/ metal interface. The mechanical properties and elastic modulus in compression for the void-metal composite are closer to those of living bone. One consideration with this type of porous implant is that voids reduce the strength of the prosthesis. No reference to clinical use of this material was found. 
Wire mesh and fiber metal titanium coating on a Ti-6Al-4V substrate have been studied ${ }^{39}$. These coatings are made of 50 um to 100 um diameter wire. Pressure sintering of the wire mesh permits the use of sintering temperatures of $800^{\circ}$ to $900^{\circ} \mathrm{C}$ which are below the beta titanium transformation temperature of $975^{\circ} \mathrm{C}$ for the $\mathrm{Ti}-6 \mathrm{Al}-4 \mathrm{~V}$ used in the study. There was some loss of strength in these coatings after sintering. Coatings of $316 \mathrm{~L}$ stainless steel were made and bone tissue grew equally well into both materials. Lining the inside of the pores of the Ti-6A1-4V fiber metal coating with a 20 um layer of hydroxyapatite 27 enhanced bone ingrowth initially by a factor of four, but this was a short term effect lasting only a few weeks. Interfacial decohesion between bone and implant was increased by a factor of two. Porous coatings on $\mathrm{Ti}-6 \mathrm{Al}-4 \mathrm{~V}$ have been made by sintering spheres of $\mathrm{Ti}$ or $\mathrm{Ti}-6 \mathrm{Al}-4 \mathrm{~V}$ on to the Ti-6Al-4V substrate 40,41 , but sintering above the beta titanium transformation temperature results in an elongated alpha titanium microstructure and a reduction in fatigue strength. This loss in fatigue strength also was attributed to stress raising effects in the porous surface and at the particle/substrate interface. One of the first studies of porous metal surgical implants was made by Hirschhorn and Reynolds 42 who compacted Co-Cr alloy powders of alloy HS-21 (the castable alloy) and HS-25 (the wrought material.) Hirshhorn and Reynolds demonstrated the feasibility of using porous implants by obtaining bone growth into the implant and by attaining a lower elastic modulus for the porous material. The recommended porosity was 30 percent for an alloy such as HS- 25 .

Today, a widely used sintered porous Co-Cr-Mo coated Co-Cr-Mo implant is made by high temperature sintering of the spheres onto the surfacel. Metal powders or spheres made from material of the same composition as the substrate are produced by the gas atomization process or the spun electrode process. Resulting irregular 
shapes and/or spheres have a fine cast structure prior to sintering. These particles may be held to the substrate by means of an inorganic binder. The binder could be a source of contamination, but this is not necessarily the case, depending on the nature of the binder. Sintering at temperatures in the $1200^{\circ} \mathrm{C}$ to $1300^{\circ} \mathrm{C}$ range results in interparticle or particle/substrate connections or necks which form probably by a diffusion process. The microstructure within the spheres changes to large grains similar to that of the substrate with second phase regions present in both coating and substrate. The shear strength of this porous coating exceeds $21 \mathrm{MPa}^{43}$. Kilner44 discusses melting of the interdendritic phase (a eutectic consisting of carbide, sigma and cobalt rich phases) and the resulting detrimental effects on the mechanical properties, and suggests that very slow cooling from the sintering temperature to $1235^{\circ} \mathrm{C}$ helps to prevent long continuous carbide phase formations. This slow cooling may not be practical in actual production. However, due to the presence of these phases and the possible detrimental effects on mechanical properties, the processing temperatures, cooling procedures and composition are important aspects of porous coated Co-Cr-Mo implants. It is important for the porous coating to have the same composition as the substrate and if not, to identify phase compositions and other factors which would adversely affect the strength or corrosion behavior of the porous coated implant.

Fiber metal implants ${ }^{2}, 45$ are made of pure Ti fibers, $0.19 \mathrm{~mm}$ in diameter and $6.35 \mathrm{~mm}$ long and are kinked and pressed into the needed shape prior to sintering. Fibers also are cut in lengths ranging from 1.3 to $3.8 \mathrm{~cm}$. The piece is sintered in vacuum at $1070^{\circ} \mathrm{C}$ to $1240^{\circ} \mathrm{C}$ for one to four hours. This piece can be pressed a certain amount after sintering to correct for any shape changes. Machining is not recommended as it tends to close surface porosity. The fiber metal part shows good ingrowth and high bone-implant interfacial strength. This fiber metal part 
may be used as a bone segment or the fiber metal pressed shape can be fitted mechanically into a shaped area of a hip stem or other prosthesis to provide for attachment to a solid core. This fitting may be followed by sintering. Sintering at temperatures above the beta transus should be avoided and care should be taken at any sintering temperature not to introduce oxygen into the material since detrimental effects on the fatigue 1 ife and other mechanical properties of the prosthesis could result This type of porous coating has been used in clinical trials and data should be available soon on the result or actual use of this material. Co-Cr-Mo and $316 \mathrm{~L}$ stainless steel wires ${ }^{39}$ have been studied for use as fiber metal parts, but titanium has been the material of choice for extensive investigation.

The arc plasma sprayed porous metal coating ${ }^{3}, 46$ on a metal substrate is being used clinically for dental implants, for backs of acetabular cups, and on various areas of femoral stems. This coating usually is Ti or Ti-6Al-4V applied to a Ti-6Al-4V substrate. Other materials such as $\mathrm{Co}-\mathrm{Cr}-\mathrm{Mo}$ also have been applied to metal substrate using this process. The coating is applied by spraying metal powders in size ranges of 200 um to 100 um or other specified size using a carrier gas such as argon. The plasma flame may have a temperature of $15,000^{\circ} \mathrm{C}$ and the gas speed is $3000 \mathrm{~m} / \mathrm{sec}$. Prior to the application of the coating, the substrate is grit blasted with $\mathrm{Al}_{2} \mathrm{O}_{3}$ to produce a roughened surface. This grit blasting is a possible source of contamination since some $\mathrm{Al}_{2} \mathrm{O}_{3}$ particles or other grit blasting material may become embedded in the surface and not be removed in the cleaning process which follows. Porous surfaces applied in this manner form strong bonds to the substrate and may be applied to produce a wide range of porosities. Mechanical properties, including fatigue life, are not adversely affected by the application of this porous coating. The Ti-6AT-4V material must not be sintered above the beta titanium transformation temperature if desirable mechanical properties of the Ti-6AT-4V substrate are to be maintained. Indications are that this coating 
does not need to be sintered.

\section{Corrosion}

The biocompatibilities of the materials discussed in this paper have been studied by Laing 47,48 and others, and the referenced investigations of the porous materials indicate that no extensive unusual cellular behavior in the bony ingrowths was observed. Questions remain about metal ion release and short and long term effects. Initial studies of this topic have been made by $B 1$ ack 49 , Woodman 50,51 and others to show that ions are present and are carried through the body. Metal ions are released by the process of corrosion. Corrosion studies of porous Ti-6AT-4V fiber metal implants by Lautenschlager, et al.52, and of sintered Co-Cr-Mo spheres by Cameron et a $7^{53}$ indicated no changes in the electrochemical behavior except for increased corrosion currents which resulted from the increased surface area. The rate of reaction per unit of surface area was the same for the porous and the solid implants. Other corrosion studies 54 of sintered Co-Cr-Mo spheres support these earlier findings. There still are considerations regarding creviced areas and variations in the composition and location of second phases in the implant which could affect the corrosion behavior. Preliminary studies 55 on some other porous materials indicate that contamination can occur during the production of the implants which affects the corrosion resistance of the materials.

\section{Clinical Results}

Some results of clinical studies are being reported. Engh56 reports on 26 patients who were monitored over a five year period. These patients received the fully porous coated Moore prosthesis. Engh reports the short term success of this prosthesis and technique to be about the same as that for the cemented hip prostheses. He noted that bone remodelling in these cases had been a continuous process and no stress shielding or bone resorption had occurred. The importance 
of the porous surface for increased bony ingrowth and three dimensional interlocking was emphasized as well as the design of the Moore prosthesis which fits tightly in the bone. No infection occurred and no prostheses were removed from patients in this study group. All reports on stabilization of the implanted device by bony ingrowth stress the importance of avoiding micromotion of the device. The design of the device, the fit of the device and the rate of bony ingrowth are important factors which contribute to the degree of success of the prosthesis.

Lord and Bance ${ }^{57}$ gave a seven year report on 1509 cementless total hips with madreporic prostheses. The prosthesis stem includes a single layer of spheres cast together with the prosthesis. This coating is not porous but has an irregular surface for bony attacnment. The acetabular component is a threaded metal back which screws into place, and this component is lined with ultra high molecular weight polyethylene. In this number of cases, problems such as infection (26 cases), dislocations ( 68 cases), femoral shaft fractures ( 57 cases), hematomas ( 35 cases), transient sciatic palsy ( 4 cases), greater trochanter avulsions ( 57 cases), ectopic bone formation (131 cases) and stem fractures ( 3 cases) were observed. The numbers are broken down into various groups relating to time of installation or problem. Overall results for 235 cases for a five year period are 139 rated as excellent, 57 as good, 24 as fair and 15 as poor. The authors state that the madreporic prosthesis is a safe, reliable procedure for individuals with reasonably good bone stock. Ring 58 reports on 471 uncemented metal on plastic hips installed in $1980-1982$. The results obtained were better than those with uncemented metal on metal prostheses and were comparable with results from cemented metal on plastic prostheses. The acetabular component of the Ring prosthesis is a conical shape and must be axially located. Infection is less of a problem than with the cemented prosthesis and revision surgery can be accomplished with ease and without having to remove all components of the prosthesis. 
Kuo, et a1.59 report on reconstruction of long bones following tumor removal accomplished by implanting segments of solid core Ti-6Al-4V alloy coated with pure titanium fiber metal. Results were excellent in 11 cases, satisfactory in five and there was one failure. The one failure resulted from infection and the patient's request not to undergo further surgery. Function was possible for this patient with the use of a brace. Additional surgery and bone grafting were required for the satisfactory cases. Case summaries are given for the 17 patients.

Clinical studies of total knees were summarized by Hungerford and Kenna23. Other research studies 60 on porous polysulfone coated Co-Cr-Mo stems placed in dogs show that this coating supports bony ingrowth. Clinical studies of cementless fixation using a polyacetal resin coated metal prosthesis are in progress 61 . The polyacetal resin alone proved to be too elastic and the metal was added for strength.

The bone remodelling continues over many months. Studies in dogs by Chen62, et al showed progressive ingrowth in three and six month observations. These studies showed some osteoporosis which did not appear to be progressive. Progressive active bone remodelling was observed through the experimental period. This study also stressed the importance of initial firm fixation and close contact of the prosthesis with the bone as well as the design of the device. This study also mentioned the potential possibility of prosthesis removal which necessitates leaving as much bone as possible in the initial installation.

The difference in bone growth rates in animals and older humans is striking63. Histology studies were made of bone tissue taken from an eighty seven year old woman after 40 days of implantation and of an eighty two year old man after a 6.5 month implantation period. Bone ingrowth and adaptive bone modelling were observed but the degree of ingrowth and fixation were less than that observed in animal models. This difference was attributed partially to the patient's ages and inactivity. The overall histological appearance of tissue adjacent to the prosthesis was that the 
tissue was benign and free of foreign cell reaction. No macrophage activity and no inflammatory responses were observed. Both patients suffered from some osteoporosis and bone disease prior to implantation of the devices.

Galante 64 summarized the current status of cementless fixation briefly in introductory statements to several articles referenced here. He noted that cementless fixaction is more widely used in Europe and is not always based on bony ingrowth but also on bony attachment to irregular surfaces. Two important prerequisites for bony ingrowth are close contact between prosthesis and bone and rigid immobilization. More clinical data are needed on porous coated and other cementless prostheses. Reports by clinicians and researchers will be useful in evaluating and developing these devices.

14 
1. Welsh, R. P., Pilliar, R. M. and MacNab, I., Surgical Implants: The Role of Surface Porosity in Fiyation to Bone and Acrylic, J. Bone and Joint Surgery, 53A, (5), 963-967 (1971).

2. Galante, J., Rostoker, W., Lueck, R. and Ray, R. D., Sintered Fiber Metal Composites as a Basis for Attachment of Implants to Bone, J. Bone and Joint Șurgery, 53-A (1), 101-114, 1971 .

3. Hahn, H., and Palich, W., J. Biomed. Mater, Res., Vol. 4, p. 571 (1970). Preliminary Evaluation of Porous Metal Surfaced Titanium for Orthopedic Implants.

4. Proceedings of the Workshop on Internal Joint Replacement, Northwestern University, Chicago, Illinois, March 3-5, 1977.

5. Arthur D. Little Report, 1982.

6. NIH Consensus Development Conference, Total Hip Replacement, March 1-3, 1982, Gordon, Stephen L., coordinator, National Institute of Arthritis, Diabetes and Digestive and Kidney Diseases.

7. Kelsey, Jennifer L., Yale University School of Medicine, Epidemiology and Impact." ibid.

8. Johnston, Richard C., The Hip Society, "Long Term Outcomes - Hip Society Collective U.S. Experience," ibid.

9. GaTante. Jorge 0., Rush Presbyterian-St. Lukes Medical Center, "Total Hip Joint Replacements," ibid.

10. Klawitter, J. J. and Weinstein, A. M., The Status of Porous Materials to Obtain Direct Skeletal Attachment by Tissue Ingrowth. Acta Orthopaed. Belgica, Tome 40, Fasc. 5-6, 755-765, 1974.

11. Ring, P. A. J Bone and Joint Surg., 50B, 720-731, 1968.

12. Charnley, J., J. Bone and Joint Surg., 47B, 354-363, 1975.

13. Charniey, J., J. Bone and Joint Surgery, 42B, 28 (1960).

14. Ducheyne, P., Martens, M., Aernoudt, E. Mutier, J. and De Meester, P., Skeletal Fixation by Metal Fiber Coating of the Implant, Acta Orthopaed. Belgica, Tome 40, Fasc. 5-6, 1974.

15. Homsey, C. A., Tullos, H. S., Anderson, M. S., Diferrante, M. M. and King, J. W. Clinical Orthoped. and Related Research, No. 83, 317, 1972.

16. Amstutz, H. C., Lurie, L. and Bullough, P., Clinical Orthoped. and Related Research, No. 84, 163, 1972. 
17. Spector, Myron, Bone Ingrowth into Porous Metals, Biocompatibility of Orthopedic Implants, Vol.II, CRC Series in Biocompatibility, Boca Raton, FL, Ed. David F. Williams, Chapter 5, 89-128, 1982.

18. Porocoat, DePuy, Div. of Boehringer Mannheim Corp., P.0. Box 988, Warsaw, IN 46580 Approx. 1982.

19. Pilliar, R. M., Powder Metal-Made Orthopedic Implants with Porous Surface for Fixation by Tissue Ingrowth, Clin. Orthoped. and Related Res., 1 (6), 42-51, 1983.

20. Hulbert, S. F., Morrision, S. J. and Klawitter, Tissue Reaction to Three Ceramics of Porous and Non-porous Structures, J. J., J. Biomed Mater. Res. 6, p. 347-374 (1972).

21. Bobyn, J. D., Wilson, G. J., MacGregor, D. C., Pilliar, R. M. and Weatherly, G. C., Effect of Pore Size on the Peel Strength of Attachment of Fibrous Tissue to Porous-Surfaced Implants, J. Biomed. Mater. Res., 16, 571-584, 1982.

22. Hungerford, D. S., Kenna, R. V. and Krackaw, K. A., The Porous Coated Anatomic Knee, Orthop. Clin. North Am: 13, 103-122, 1982.

23. Hungerford, D. S. and Kenna, R. V., Preliminary Experience With Porous Coating Used Without Cement, Clin. Orthop. 176: 95-107, 1983.

24. Salman, N. N., The Effect of Direct Electrical Current Stimulation on the Bone Growth into Porous Polymeric, Ceramic and Metallic Implants, PhD. Dissertation, Clemson University, Clemson, SC, 251 pages, 1980.

25. Brighton, Carl T., Guest Ed., Urist, Marshall R., Ed., Symposium on Bioelectric Effects on Bone and Cartilage, Clinical Orthopaedics and Related Research, No. 124, May, 1977.

26. Brighton, Carl T., Guest Ed., Symposium on Electrically Induced Osteogenesis, The Orthopedic Clinics of North America, W. B. Saunders Co., Phil., PA, 15 (1), 1984.

27. Ducheyne, P., Hench, L.L., Kagan, A., Martens, M., Burssens, A. and Mulier, J. C., Effect of Hydroxyapatite Impregnation on Skeletal Bonding of Porous Coated Implants, J. Biomed. Mater Res., 14, 225-237, 1980.

28. Lemons, J. E., Tricalcium Phosphate Biodegradable Ceramic, ASTM Spec. Tech. Pub. 859, Symposium on Corrosion and Degradation of Implant Materials, Eds. A. C. Fraker and C. D. Griffin, to be published, 1985.

29. Goldstrohm, G. L., Roberts, J. M. and Mears, D. C., Replacement of Canine Segmental Bone Defects with Tricalcium Phosphate Ceramic Implants., Trans. Orthop. Res. Soc., 8, 235,1983 .

30. Brown, Walter E. and Chow, Laurence C., Patent Pending.

31. De Groot, Klaas, Ed., Bioceramics of Calcium Phosphate, CRC Press, Inc. Boca Raton, $\mathrm{FL}, 1983$. 
32. Nilles, J. H., Coletti, J. M., Jr. and Wilson, C., Biomedical Evaluation of BonePorous Material Interfaces, J. Biomed. Mater. Res., I, 231, 1973.

33. Predicki, P. Stephan, J. E., Auslaender, B. A., Mooney, V. L. and Kirkland, K., Kinetics of Bone Growth into Cylindrical Channels in Aluminum Oxide and Titanium, J. Biomed. Mater. Res., 6 , 375, 1972.

34. Harris, William H., White, Richard, E., Jr., McCarthy, Joseph C., Walker, Peter S. and Weinberg, Edith H., Bony Ingrowth Fixation of the Acetabular Component in Canine Hip Joint Arthroplasty, Clin. Orthopaed. and Rel. Res., I (6) 12, 1983.

35. Judet, R., Sigiver, $M_{0}$ and Judet, T., An Uncemented Total Hip Prosthesis. J. Bone and Joint Surg: 57 (B), 396, 1975.

36. Judet, R., Sigiver, M. and Judet, T., A Non-Cemented Total Hip Prosthesis, Clin. Orthop., 137, 76-84, 1978.

37. Lord, G. A., Hardy, J. R. and Kummer, F. J., An Uncemented Total Hip Replacement. Experimental Study and Review of 300 Madreporique Orthoplasties, Clin. Orthop. 141, 2, 1979.

38. Wheeler, K. R., Karagianes, M. T. and Sump, K. R., Porous Titanium Alloy for Prosthesis Attachment, Titanium Alloys in Surgical Implants, Eds. H. Luckey and F. Kub7i, ASTM STP 796, 241-254, 1983.

39. Ducheyne, P., Martens, M., DeMeester, P. and Mulier, J. C., Titanium Implants with Porous Structures for Bone Ingrowth: A General Approach, ibid., 265-279.

40. Clemov, A. J. T., Weinstei, A. M., Klawitter, J. J., Koeneman, J. and Anderson, J., Interface Mechanics of Porous Titanium Implant, J. Biomed. Mater. Res., 15, 73-82, 1981.

41. Yue, S., Pilliar, R. M. and Weatherly, G. C., The Effect of a Porous Coating on the Fatigue Resistance of Ti-6A1-4V Al1oy, Trans. 10th Ann. Meet. of the Soc. for Biomater., Wash. DC, Vol. VII, 332, 1984.

42. Hirschhorn, J. S. and Reynolds, J. T., Powder Metallurgy Fabrication of Cobalt A7loy Surgical Implant Materials, Research in Dental and Medical Materials. Plenum Press, New York, 137-150 (1969).

43. Pilliar, R. M., Cameron. H. U. Macnab, I., Porous Surface Layered Prosthetic Device, J. Biomed. Eng. 10, 126, 1975.

44. Kilner, T., The Relationship of Microstructure to the Mechanical Properties of a Co-Cr-Mo Alloy Used for Prosthetic Devices, Ph.D. THesis, University of Toronto, Toronto, Ontario, Canada, 1984.

45. Galante, J. and Rostoker, W., Fiber Metal Composites in the Fixation of Skeletal Prosthesis, J. Biomed. Mater. Res. Sym. John Wiley \& Sons, Inc., NY, NY (4) 43-61, 1973. 
46. Hahn, H., Rowe, R., Lare, P. J., Fraker, A. C. and Ordway, F., Symposium on Corrosion and Degradation of Implant Materials, May 1983, ASTM STP 859, To be published, 1985.

47. Laing, P., Compatibility of Biomaterials, Orth. Clinics of N. Am., 4 (2), $249-275,1973$.

48. Laing, P., Clinical Experience with Prosthetic Materials: Historical Perspectives, Current Problems and Future Directions, Corrosion and Degradation of Implant Materials, Eds. B. Syrett and A. Acharys, ASTM STP 684, 199-211, 1979.

49. Black, J., Systemic Effect of Biomaterials, Biomaterials, 5, 11-18, 1984.

50. Woodman, J. L., Black, J. and Nunamaker, D. N., Release of Cobalt and Nickel from a New Total Finger Joint Prosthesis Made of Vitallium, J. Biomed. Mater. Res., 17, 655-668, 1983.

51. Woodman, J. R., Jacobs, J. J., Galante, J. O. and Urban, R. M., Titanium Release from Fiber Metal Composites in Baboons - A Long Term Study, Trans. Orthop. Res. Soc., 7, 166, 1982.

52. Lautenschlager, E. P., Sarker, N. K., Acharya, A., Galante, J. 0. and Rostoker, W., Anodic Polarization of Porous Fiber Metals, J. Biomed, Mater. Res., $\underline{8}, 189,1974$.

53. Cameron. H. V., Pilliar, R. M. and MacNab, I., Porous Vitallium in Implant Surgery, J. Biomed. Mater. Res., 8, 283, 1974.

54. Van Orden, A. C. and Fraker, A. C., Effects of Porous Coatings on the Corrosion Behavior of Co-Cr-Mo Material, Trans. 10th Ann. Meet. Soc. for Biomater., Wash, DC, VII, 123, 1984.

55. Fraker, A. C., unpublished research.

56. Engh, Charles, A., Hip Arthoplasty with a Moore Prosthesis with Porous Coating: A Five-year Study, Clin. Orthopaed. and Re1. Res., I (6) 52, 1983.

57. Lord, G. and Bancel, P., The Madreporic Cementless Total Hip Arthoplasty: New Experimental Data and a Seven-year Clinical Follow-up Study, ibid. 67.

58. Ring, P.A., Ring UPM Total Hip Arthroplasty, ibid. 115.

59. Kuo, Ken K.; Gitelis, Steven; Sim, Franklin H.; Pritchard, Douglas; Chao, Edmund; Rostoker, William; Galante, Jorge 0. and McDonald, Patrick, Segmental Replacement of Long Bones Using Titanium Fiber Metal Composite Following Tumor Resection, ibid. 108.

60. Spector, M., Davis, M. D. Lunceford, E. M. and Harmon, S. L., Porous Polysulfone Coatings for Fixation of Femoral Stems by Bony Ingrowth, ibid. 34. 
61. Morscher, E. W. and Dick, W., Cementless Fixation of "Isoelastic" Hip Endoprostheses Manufactured from Plastic Materials, ibid. 77.

62. Chen, Po-Quang, Turner, Thomas M., Ronnigen, Helge, Galante, Jorge, Urban, Robert, and Rostoker, William, A Canine Cementless Total Hip Prosthesis Model, ibid. 24.

63. Bobyn, J. Dennis and Engh, Charles, Human Histology of the Bone-Porous Metal Implant Interface, Orthopedics, I, (9), 1410, 1984.

64. Galante, Jorge 0., Guest Editor Editorial Comment, Clin. Orthopaed. and Rel. Res., $\underline{l},(6) 2,1983$. 



\section{Part II}

Corrosion Behavior of Sintered Porous Coated Co-Cr-Mo Surgical Implant Metal 

Corrosion Behavior of Sintered Porous-Coated Co-Cr-Mo Surgical Implant Metal

\section{Introduction}

Porous coatings are being applied to metal prostheses in an effort to improve fixation of the device by bony ingrowth or in some cases, by providing stronger mechanical attachment for the poly(methyl methacrylate) cement. The Co-Cr-Mo material in the cast condition has been used successfully for permanent implants since the $1930 s^{1}$. In recent years, improvements in the mechanical properties and especially the fatigue strength of the Co-Cr-Mo material have been made by forging 2 and hot isostatic pressing ${ }^{3}$. These processes result in the reduction of the grain size from that of the cast material by many orders of magnitude. The Zimmer, USA company uses isostatically pressed material and the forged high strength material is available from Howmedica, Inc., Rutherford, NJ. These materials probably are available from other sources as well.

The sintered porous coatings produce another modification of the Co-Cr-Mo material which is not for the purpose of increasing strength but for providing a porous surface which bone may grow into and attach itself 4 . The Co-Cr-Mo porous coated material is prepared by binding $\mathrm{Co}-\mathrm{Cr}-\mathrm{Mo}_{\mathrm{O}}$ spheres to the $\mathrm{Co}-\mathrm{Cr}-\mathrm{Mo}$ substrate and sintering in a temperature range of $1150^{\circ} \mathrm{C}$ to $1300^{\circ} \mathrm{C}$. The binder should burn off and leave no residue. Details of the preparation of the porous coating such as sintering temperature, cooling rate, binder, etc, are proprietary.

There always is concern regarding metal ion release or the release of any foreign substance into the body. Earlier corrosion studies were made by Cameron, et al. ${ }^{5}$ who indicated no adverse effects on corrosion resistance due to the porous surface. The purpose of the present investigation was to study further the corrosion behavior of the porous coated Co-Cr-Mo material and to compare test data from solid specimens 
with data from porous specimens. Compositional changes resulting from phase changes and variations in the surface structure may alter the corrosion behavior. Results of the present study show that the corrosion per unit area is the same for the porous surface as for the smooth surface. Still, this gives an increase in metal ion release since the surface area of the porous material is increased by two or three times. Pitting and crevice corrosion were not observed with the materials studied but variations in porosity or composition could change this. The Co-Cr-Mo prosthetic devices, when placed in the body, will be in the passive condition most of the time. This condition could be altered by scratching or rubbing of the device or changes in the local pH in the area surrounding the implant. The passive condition would minimize ion release in both the solid and porous forms. The passive condition results from the formation of a surface oxide film, and studies were conducted to analyze for the composition of this film and to determine the oxidation state of the $\mathrm{Cr}$ ion which is predominant in the film. Details and results of the investigation are presented in this report. 
Materials and Methods

Materials used in this study were of a composition which fell within the limits of the ASTM F-75 specification for Co-Cr-Mo material. The porous coated materials were supplied by Howmedica, Inc., Rutherford, NJ and by DePuy, Inc., Warsaw, IN. The material from Howmedica was in the form of knee prostheses with two or three layers of 850 to 1000 um diameter spheres. Materials were provided in the unpassivated condition and in the passivated condition. The later condition involved passivation in 20 to 30 percent $\mathrm{HNO}_{3}$ as described in ASTM F-86. The material from DePuy was provided in the form of coupons. The spheres were smaller and ranged in diameter from 210 to $250 \mathrm{um}$. The porous coating consisted of three to four layers of spheres.

Gas adsorption techniques were used to determine the surface area of the porous materials. A monolayer of gas is adsorbed on a porous specimen and then is desorbed and measured. This is compared with the measured exposed area of the substrate base which has no spheres. The surface area for the layers of larger spheres was four times greater than that of the solid surface, and the surface area for the multilayered smaller spheres was six times greater than that of the solid surface.

Representative specimens were cut in cross section, mounted, polished and etched for microscopic observation. Surface structure and surface films on the porous and solid specimens were analyzed using scanning electron microscopy and energy dispersive $x$-ray analysis (EDX). These techniques permit the determination of the composition of the surface films and the underlying substrate as well as the morphology of the surface film over different porous surfaces or second phases. Flat specimens were used for study with the electron spectroscopy for chemical analysis(ESCA) equipment. These measurements provided data on the chemical compo- 
sition of the material and on the oxidation state of the elements present. It is possible with this method to do a profile across the oxide film down to the metal substrate. Emphasis in this study was on the valence of the chromium ion in the oxide layer, and standards containing $\mathrm{Cr}^{+6}$ and $\mathrm{Cr}^{+3}$ were used as references.

Corrosion tests included anodic polarization measurements and pitting and crevice corrosion testing. The porous surfaced specimens were cleaned in water and rinsed in ethanol prior to corrosion testing. Anodic polarization measurements were made on specimens exposed to Hanks' physiological saline solution. The solution was held at a temperature of $37^{\circ} \mathrm{C}$ and had a $\mathrm{pH}$ of 7.2 . Specimens were polarized potentiostatically at a rate of $0.006 \mathrm{~V} / \mathrm{min}$. until breakdown occurred. Voltage was measured versus a standard calomel electrode(S.C.E.) and all voltages mentioned in this report are with respect to this reference. These measurements involve the application of a voltage and a measurement of the current which follows. The corrosion equipment is connected to a computer which is programmed to run the test and to take the data. Three or more anodic polarization tests were made on the cast material, the material with the layers of large spheres and the material with multilayered small spheres.

Pitting and crevice corrosion tests were conducted using procedures described in the ASTM F-746 Recommended Test for Pitting and Crevice Corrosion. This is a test in which a stimulation voltage is applied to the specimen to determine if pitting is initiated. The stimulation potential for the tests with the Co-Cr-Mo material was raised from $0.8 \mathrm{~V}$ to $1.0 \mathrm{~V}$. These tests were conducted in a 0.9 percent $\mathrm{NaCl}$ solution. 


\section{Results and Discussion}

\section{Microstructures}

The microstructure of the cast material is shown in the light micrograph of Figure 1. The grain size is large and there is a second phase area which may comprise a mixture of the sigma phase, a cobalt rich phase and a carbide phase. The cross section of the spheres which were sintered onto the surface is shown in Figure 2. The structure dendritic due to rapid cooling in the production of the spheres. After sintering the spheres on to the solid substrate at elevated temperatures, the fine structure disappears and large grains form which contain second phase areas at grain boundaries and other locations. This microstructure is shown in Figure 3 and is of the material with the larger spheres. The second phase segregates in the neck areas between the spheres and at locations where the spheres attach to the substrate. The amount of this phase area and its constituents are related to the thermal treatment, cooling procedures and composition of the material. Other views of the spheres and the neck areas after being exposed to corroding conditions are shown in the scanning electron micrographs of Figures 4 and 5 . Some voids (see arrow) are present in the neck areas.

Compositions of the secondary phases at the neck areas and of the matrix material are shown in Figure 6 . These results are for the material with the multilayers of 210 to 250 um sized spheres. The secondary phase areas are enriched in $\mathrm{Cr}$ and $\mathrm{Mo}$, and this enrichment would correspond to the presence of the carbide phase(s) and the sigma phase, respectively. 


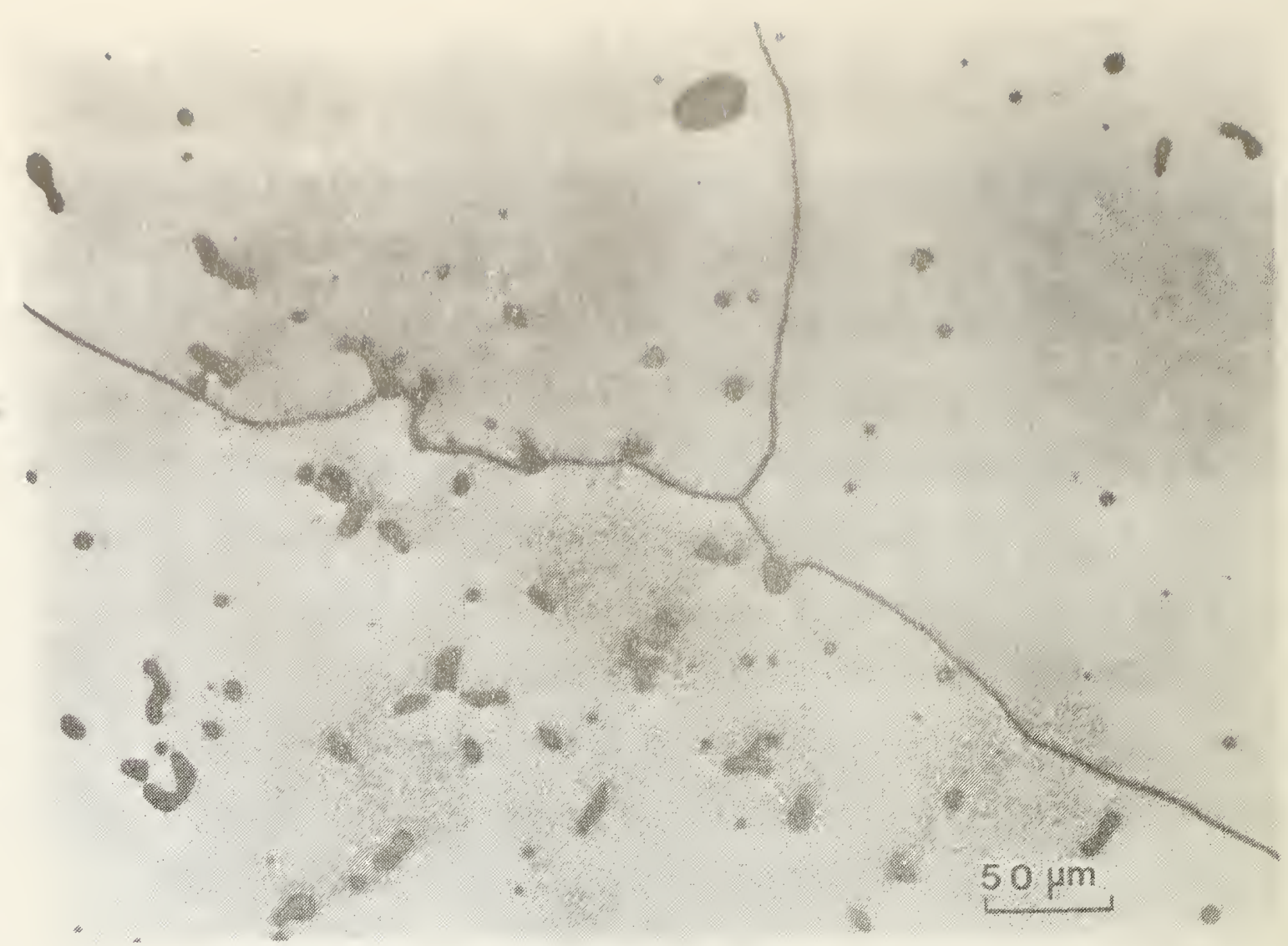

Figure 1. Light micrograph of cast Co-Cr-Mo.

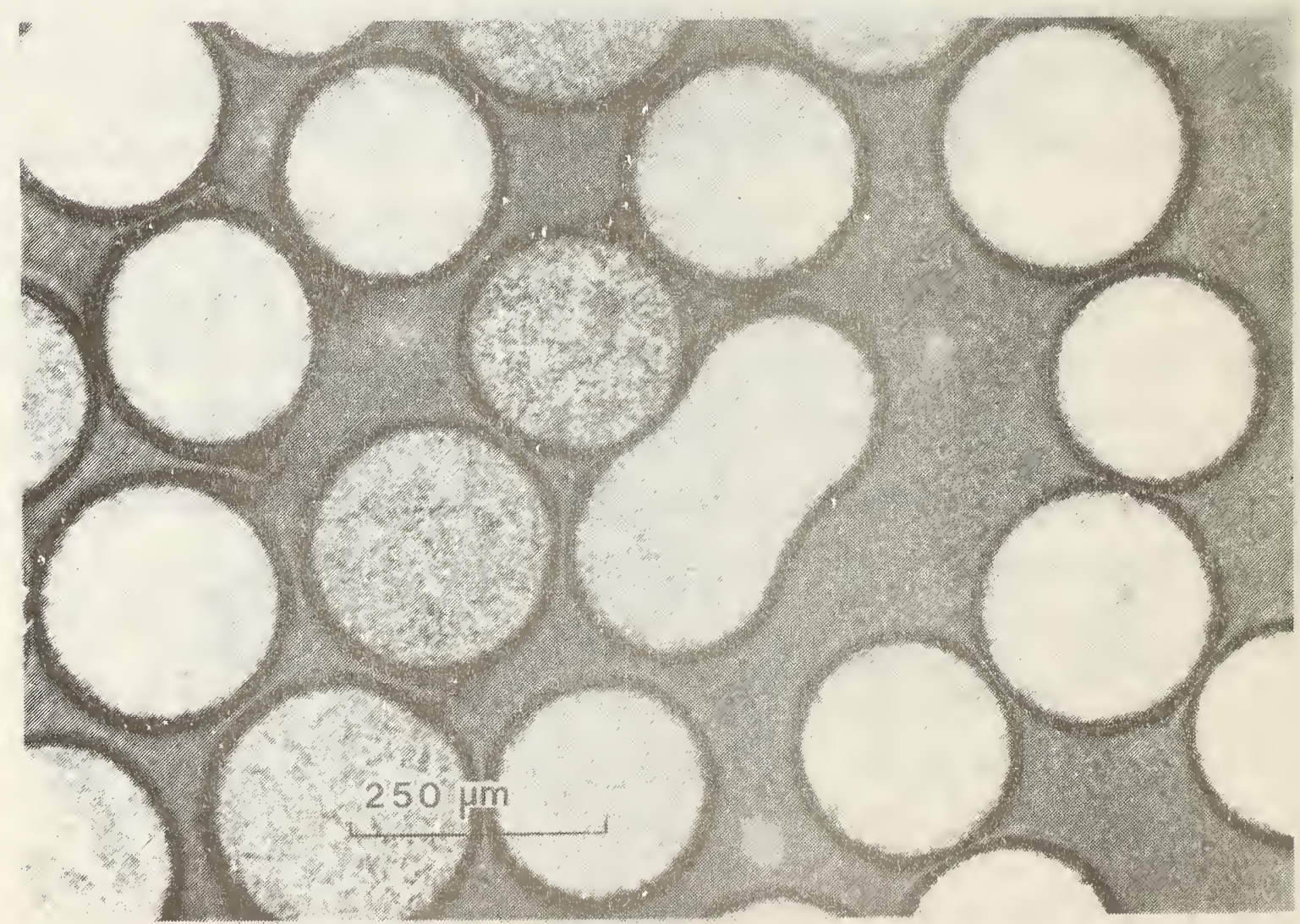

Figure 2. Light micrograph of cross sections of unsintered spheres. 


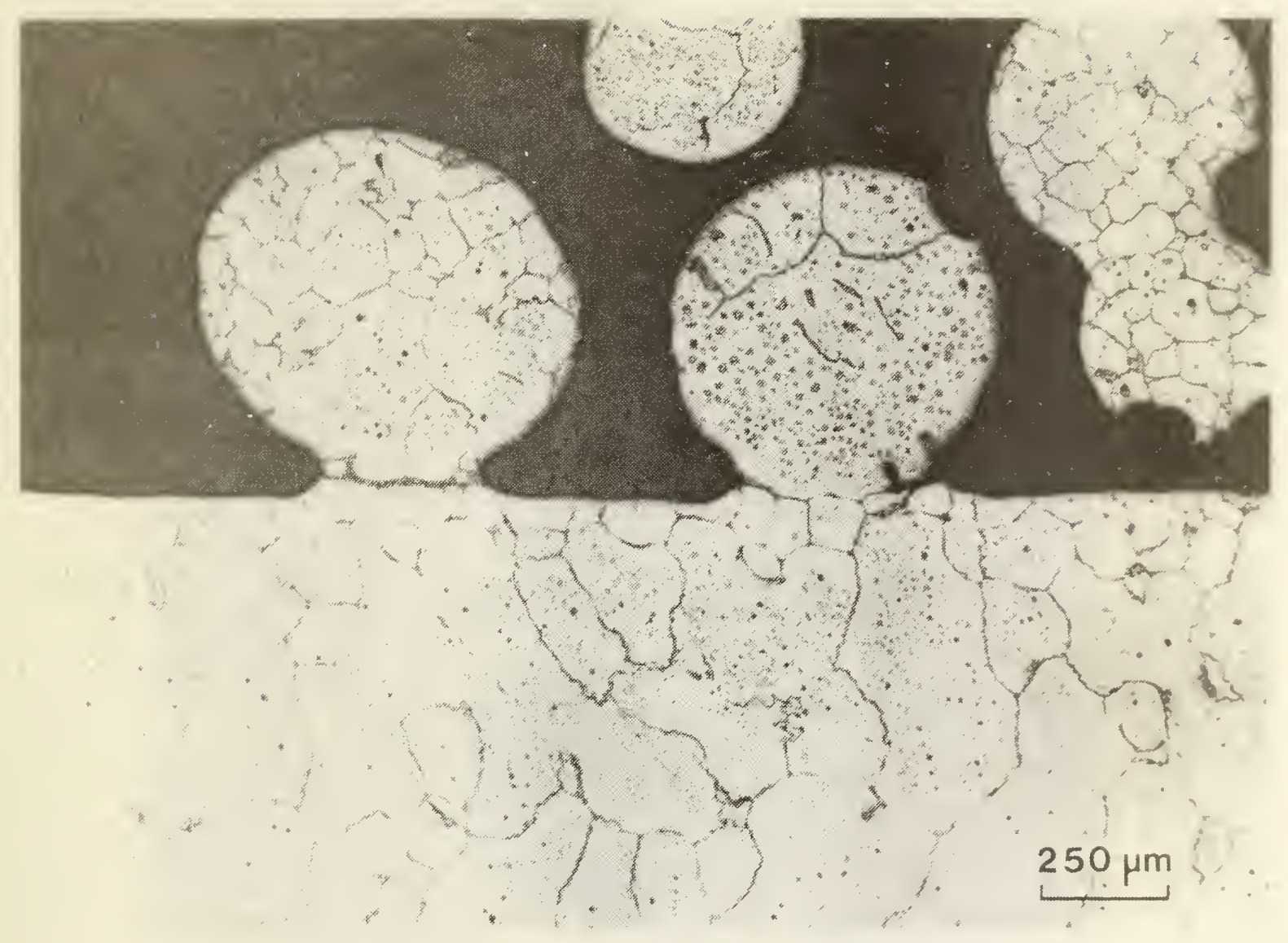

Figure 3. Light Micrograph showing microstructure of Co-Cr-Mo spheres sintered to a Co-Cr-Mo substrate. 


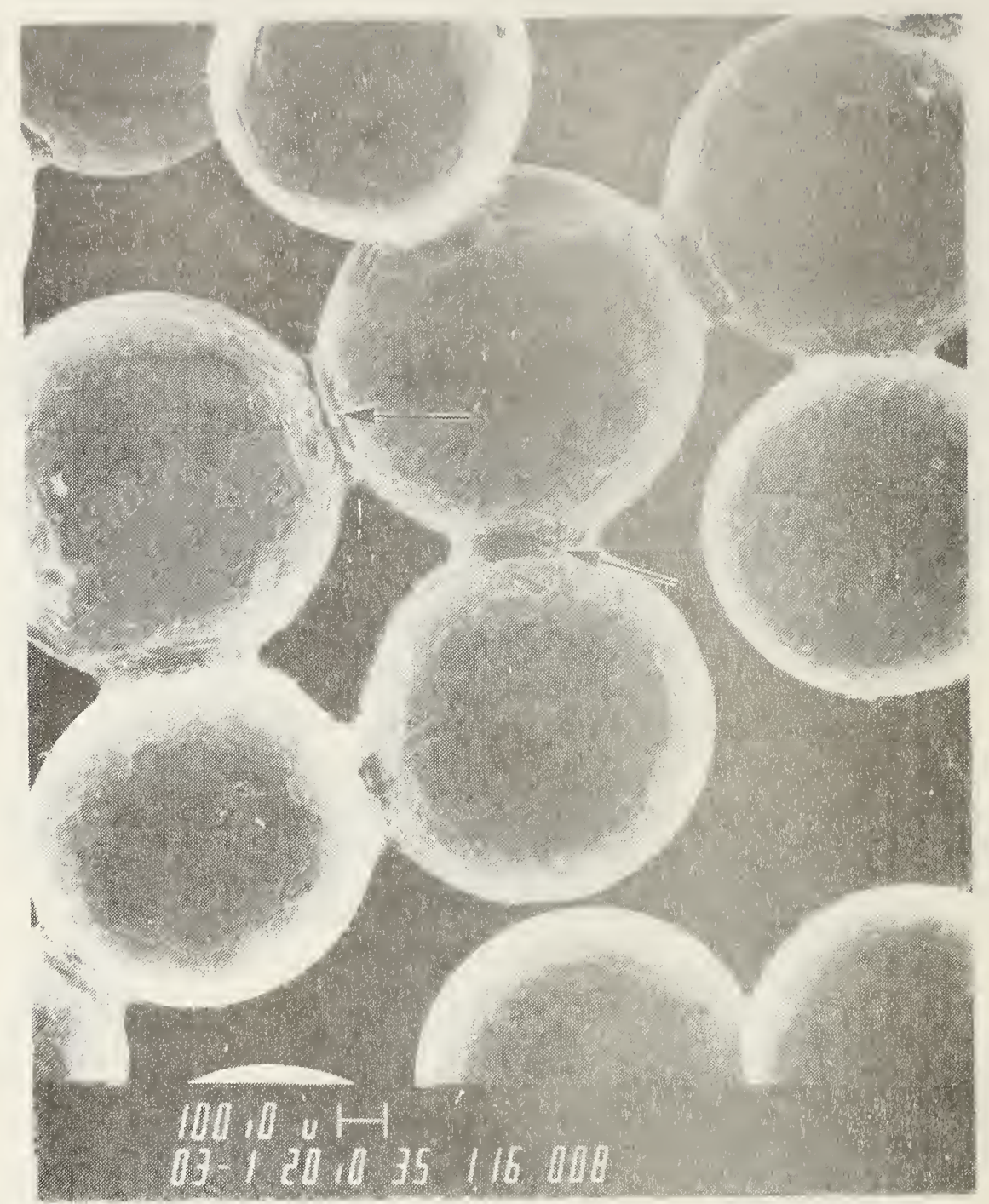

Figure 4. Scanning electron micrograph of sintered Co-Cr-Mo spheres on a Co-Cr-Mo substrate after corrosion testing. 


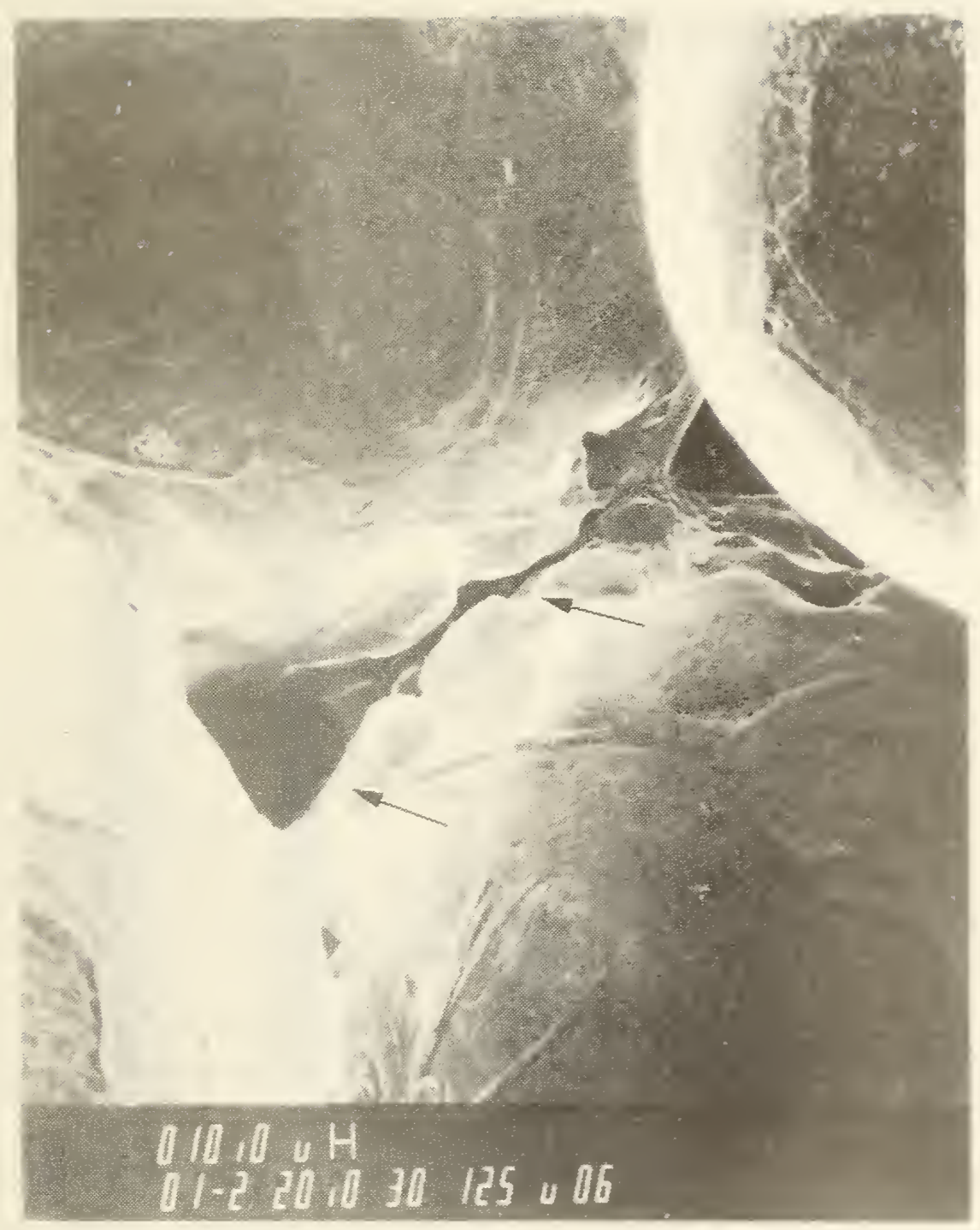

Figure 5. Scanning electron micrograph of neck region connecting sintered $\mathrm{CO}-\mathrm{Cr}-$ Mo spheres after corrosion testing. 


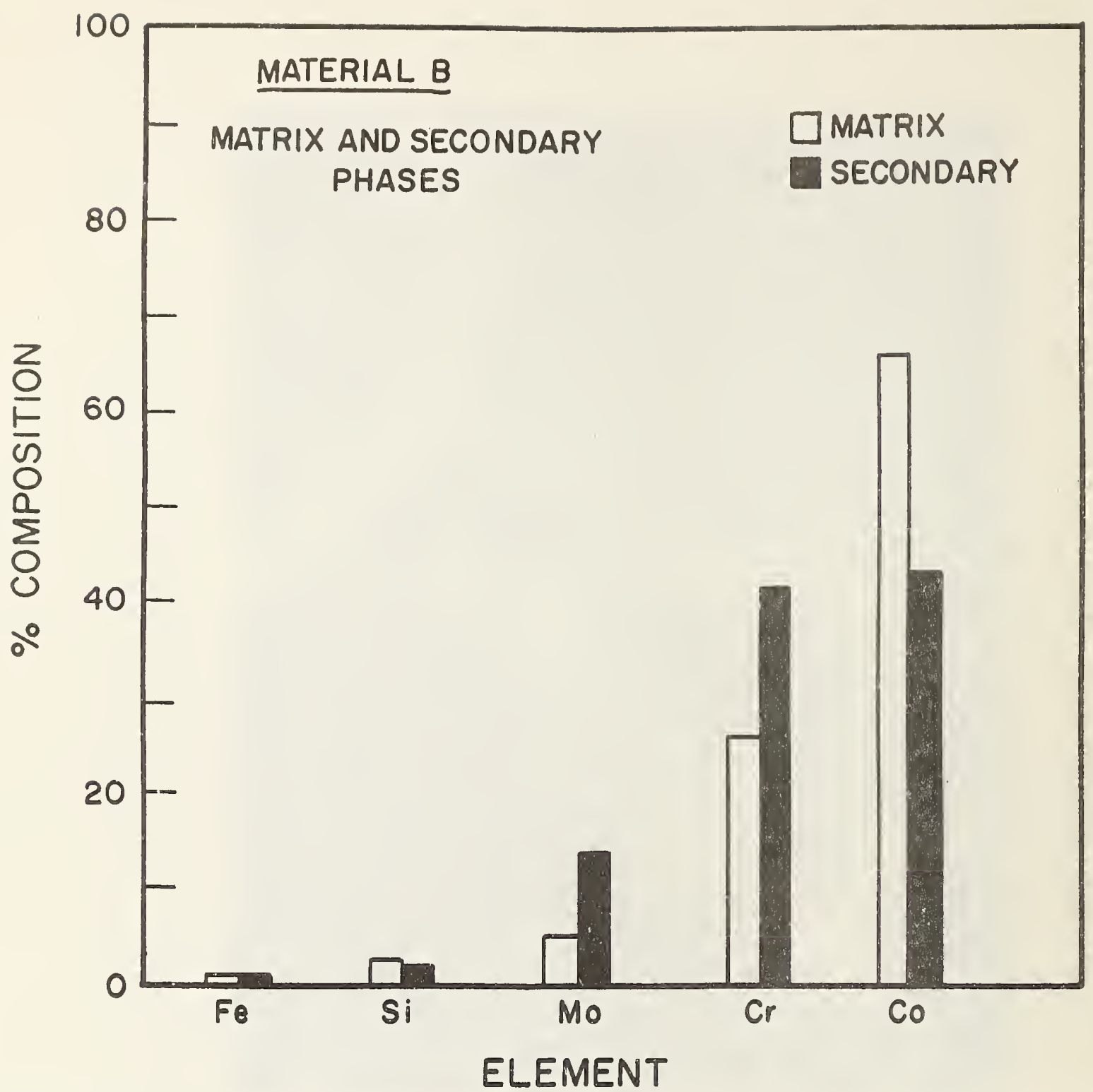

Figure 6. Bar graph of EDS data showing smounts of selected elements in different phases of Co-Cr-Mo after sintering. 
Electron spectroscopy for chemical analysis (ESCA) is a method used to examine the outer 15 to $30 \mathrm{~A}$ of the surface. Specimens were analysed to determine the valence of the chromium which was in the surface oxide film. Spectra were taken of the films formed in Hanks' physiological saline solution. Spectra were taken initially after exposure to the solution and again after ion sputtering for time intervals ranging from 20 to 40 minutes. The selected data in Figure 7 show two chromium peaks. The comparison of these peaks from the metal surface, curve $c$, with that of the standard peaks for $\mathrm{Cr}^{+3}$, curve $\mathrm{A}$, shows a good match. The comparison of the peaks from the oxide film, curve $D$, shows that this curve matches curve $A$ for the $\mathrm{Cr}^{+3}$ better than curve $\mathrm{B}$ which represents the ${ }^{+6}$ oxidation state. The distance between the two peaks also was taken in to account in making this comparison. There is some shift in the peaks for the oxide film, but the indication is that the chromium is in the +3 oxidation state.

Electrochemical Measurements

The results of the anodic polarization measurements are shown in Figures 8 and 9. This type of curve of current vs. potential shows the magnitude of the current, the passive region and the breakdown potential for a given material. The breakdown potential is denoted by a sharp rise in the current. Figure 8 shows curves for the solid specimen (Cast), the specimen with multilayers of 210 to 250 um sized spheres (B) and the specimen with multilayers of 850 to 1000 um sized spheres (C). These curves show higher current readings for the porous materials. The surface area of of the material that yielded curve $C$ is four times that of a solid specimen. The surface area of the sample with the porous surface, represented in Curve $B$, is six times that of a solid specimen. It is seen in Figure 8 that the current (and release of metal ions) is greater for a porous surface of a given flat substrate area than it is for a smooth surface of the same geometrical area. 


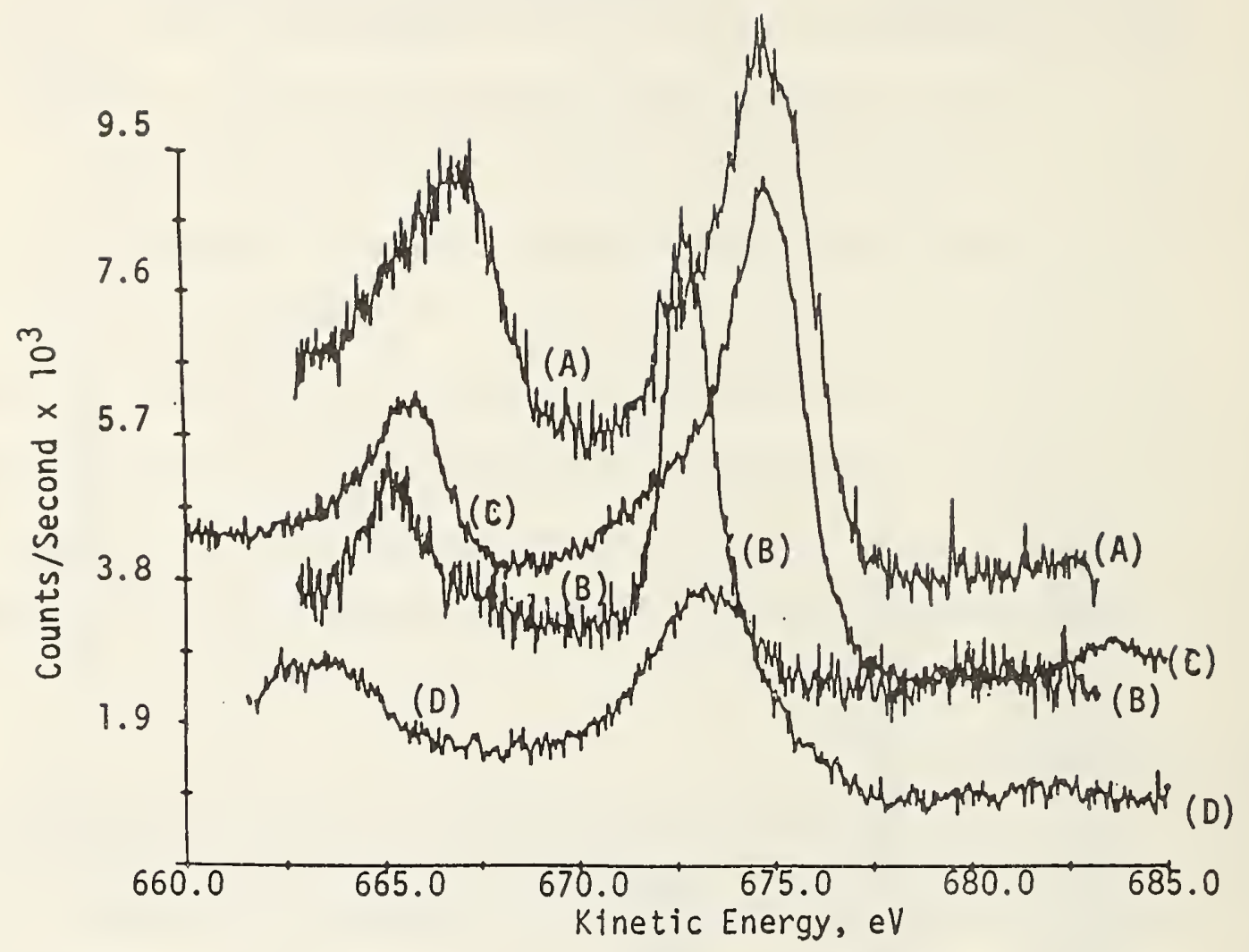

Figure 7. ESCA spectra for (A) $\mathrm{Cr}_{2} \mathrm{O}_{3}$ standard for $\mathrm{Cr}+3$,

(B) $\mathrm{K}_{2} \mathrm{Cr}_{2} \mathrm{O}_{7}$ standard for $\mathrm{Cr}^{+6}$, (C) $\mathrm{Cr}$ metal surface, and (D) oxide film. 


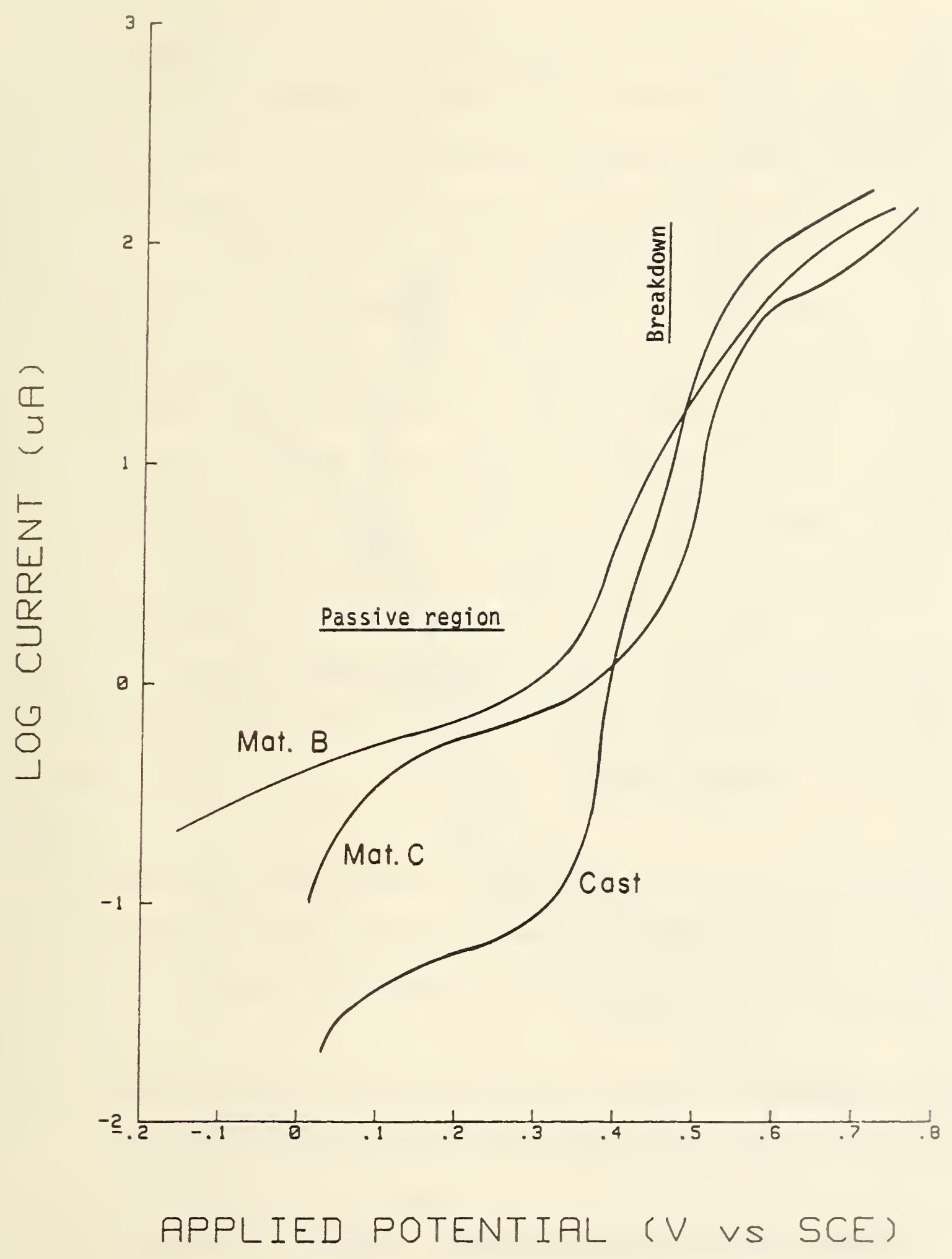

Figure 8. Anodic polarization curves for $\mathrm{Co}-\mathrm{Cr}-\mathrm{Mo}_{0}$ in the (cast), (B) sintered spheres of 210 um to 250 um diameter and (C) sintered spheres of 850 um 1000 um diameter in Hanks' physiological saline solution at $37^{\circ} \mathrm{C}$ and a solution $\mathrm{pH}$ of 7.2 . 


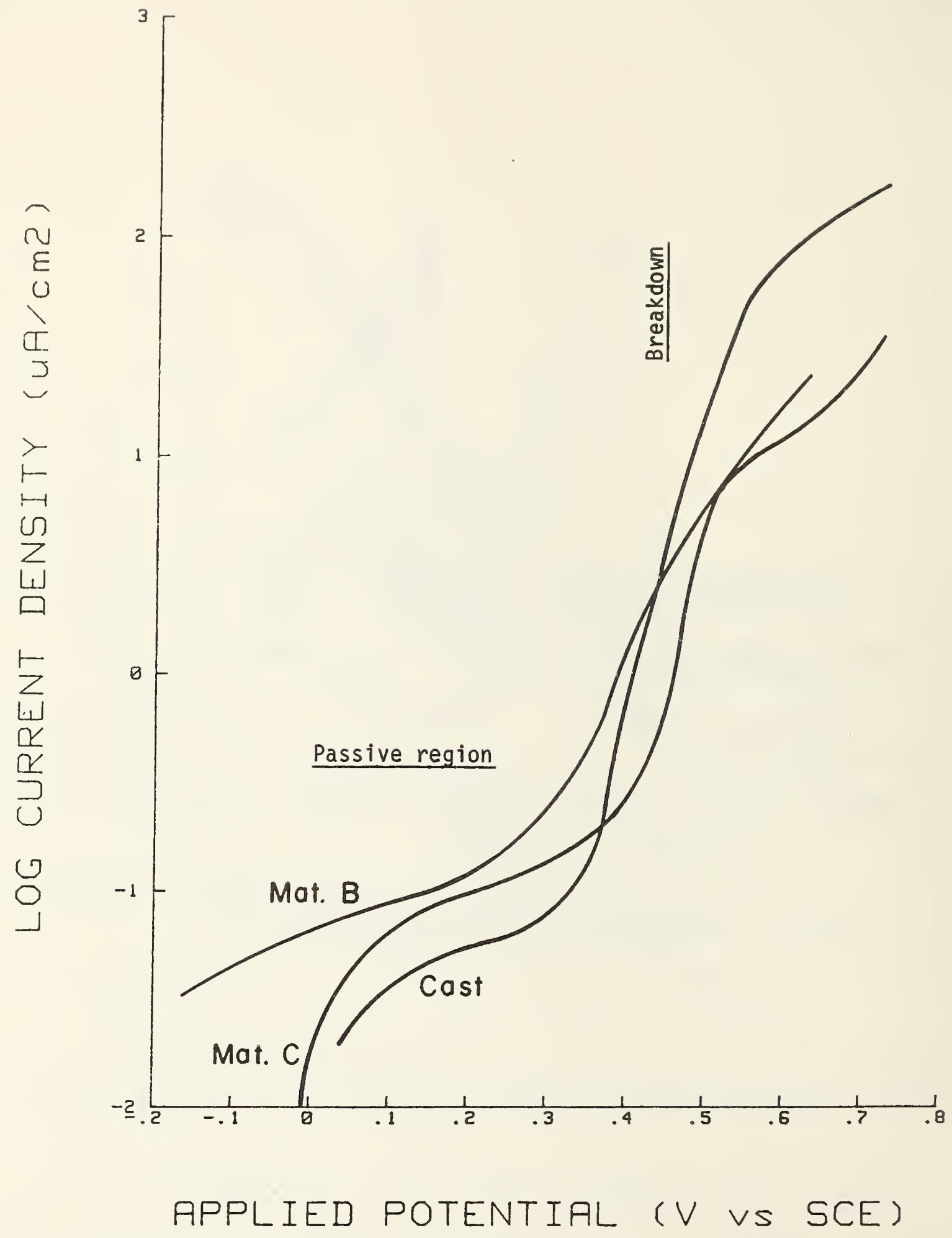

Figure 9. Anodic polarization curves for $\mathrm{Co}-\mathrm{Cr}-\mathrm{Mo}$ in the (cast), (B) sintered spheres of 210 um to $250 u m$ diameter and (C) sintered spheres of 850um to loo0um diameter in Hanks' physiological saline solution at $37^{\circ} \mathrm{C}$ and a solution $\mathrm{pH}$ of 7.2 . 
There appeared to be no basic differences in corrosion behavior between the porous and the smooth materials studied in this investigation. The current density versus the applied potential for these same specimens is shown in Figure 9. The current per unit area for the total surface is used in this figure, and this brings all of the curves closer together. The small differences which remain could be due to error in the gas porosimetry measurements of the area of the porous surface.

The breakdown potential for all specimens were very similar and approximately 0.47 volts versus S.C.E. Passivation of these Co-Cr-Mo specimens resulted in an increased breakdown potential which occurred at approximately 0.87 volts versus S.C.E.

Pitting and crevice stimulation tests were conducted on these materials, and in all cases the test was continued until the voltage reached the breakdown potential without indications of an onset of pitting or crevice corrosion. This type of local corrosion could depend on depth and size or pores as well as the composition of second phases, and the results of this study are specific to the type of materials used in this investigation.

$\underline{\text { Summary }}$

This work was an investigation of the corrosion behavior of sintered porous Co-Cr-Mo in terms of anodic polarization behavior, pitting and crevice corrosion resistance and surface film analysis. The results of this study may be summarized as follows:

1. Microstructural analysis of the sintered materials showed the presence of a second phase which often was concentrated at the neck region where the spheres sintered together and at the interface region where the spheres joined to the substrate. The second phase was found at the grain boundaries and at other locations throughout the specimen. Three different batches of 
material were examined, and the amount of this second phase was less in two of the batches.

2. Energy dispersive $x$-ray analysis showed the composition of the second phases in the neck regions to be enriched in $\mathrm{Cr}$ and Mo.

3. Anodic polarization measurements showed corrosion currents to be higher for the porous materials, but the current density for the porous and solid materials was essentially the same. The breakdown potential for both the porous and solid materials in the Hanks' solution was 0.47 volts vs. S.C.E.

4. Electron spectroscopy for chemical analysis was used to study the composition of the oxide films which were found to be a mixed oxide, predominantly chromium oxide. Results indicated that the oxidation state of the chromium in the surface film is +3 and not +6 . This determination was made using standard salts containing chromium of known valence. 


\section{$\underline{\text { References }}$}

1. Venable, C. S. and Stuck, W. G., The Internal Fixation of Fractures, C. C. Thomas, Springfield, 1947.

2. Devine, T. M. and Wulff, J., Cast vs. Wrought Cobalt-Chromium Surgical Implant Alloys, J. Biomed. Mater, Res., g (2) 151-167, 1975.

3. Luckey, H. A. and Barnard, L. J., Improved Properties of Co-Cr-Mo Alloy by Hot Isostatic Pressing of Powder, Mechanical Properties of Biomaterials and Bioceramics Symposium, University of Keele, England, G. W. Hastings, Chmn., 1978.

4. Welsh, R. P., Pilliar, R. M. and MacNab, J., Surgical Implants: The Role of Surface Porosity in Fixation to Bone and Acrylic, J. Bone and Joint Surgery, 53A, (5), 963-967, 1971.

5. Cameron, H. V., Pilliar, R. M. and MacNab, J., Porous Vitallium in Implant Surgery, J. Biomed. Mater. Res., 조 283, 1974. 



\section{Part III}

Corrosion-Fatigue Behavior of Arc Plasma Sprayed Ti or Ti-6Al-4V Coatings on Ti-6Al-4V Substrates 
Corrosion-Fatigue Behavior of Arc Plasma Sprayed Ti and Ti-6AT-4V Coatings on Ti-6Al-4V Substrates

\section{Introduction}

Commercially pure titanium and Ti-6AT-4V alloy coatings were applied to Ti-6Al-4V alloy by arc plasma spraying $1,2,3$. The coatings were applied in a manner which produced a porous coating. The coatings also can be applied in a more dense form and of other materials and then surface finished for intended uses other than surgical implants. Application of coatings in this manner results in a coating which is strongly bonded to the substrate. Test results showed that fracture occurred within the coating and not at the coating/substrate metal interface. Corrosion-fatigue behavior is not adversely affected by application of this coating, and it is subject to further improvements. The interface bond strength, fatigue strength and other mechanical and chemical properties of this coating are subject to change depending on the variation of conditions used in the production of the coating. Coatings used in this investigation were prepared under controlled conditions, and microstructures and other properties were analysed. A number of variables could influence the integrity of this coating including; the purity of the metal powder which is being sprayed, the material used for the grit blasting, the cleaning process after grit blasting, the purity of the carrier gas and other aspects of the application of the coating relating to the control of the gun, spray nozzle, etc. 
Materials and Methods

Cylindrical specimens of $2.86 \mathrm{~cm}$ diameter were coated on the ends and epoxyed together for tension testing. Flat specimens were cut from Ti-6Al-4V to a size of $2.54 \mathrm{~cm} \times 0.64 \mathrm{~cm} \times 7.50 \mathrm{~cm}$, and an arc plasma sprayed coating was applied to one side. These specimens were used in the lap shear tests. Specimens for corrosionfatigue testing were made from 0.250" diameter rod of extra low interstitial(ELI) grade Ti-6AT-4V which was obtained from Dynamet, Inc., Clearwater, Florida. These specimens were cut into $7.6 \mathrm{~cm}$ lengths, and the middle $12.7 \mathrm{~mm}$ was machined to a decreased diameter of $5 \mathrm{~mm}$. This center section was arc plasma sprayed to apply the coating, and then was exposed to the corrosive solution during torsion fatigue testing.

The arc plasma sprayed coating was applied in the following manner. Prior to coating, the designated area of the specimen was grit blasted with aluminum oxide abrasive to produce a uniform surface texture. The grit blasted area was then coated with a base layer of dense material, followed by a porous layer of material to produce a coating with graded porosity. The density and/or porosity can be controlled by varying the spraying parameters. Materials used in the coatings were $-30+325$ mesh Ti-6Al-4V powder from Consolidated Astronautics Division, United International Research, Inc., Concord, MA and ground sponge titanium from Reactive Metals, Inc. Niles, $\mathrm{OH}$. A schematic of the gun for the arc plasma spraying is shown in Figure $1^{4}$. Tests to determine the bond strength of the coating to the substrate were conducted using a lap shear method. Porous coated surfaces were filled and bonded together with Torr Seal* adhesive resin. The adhesive resin was obtained from Farian Associated, Palo Alto, CA. The two specimens were properly aligned and clamped together. The resin was cured at $60^{\circ} \mathrm{C}\left(140^{\circ} \mathrm{F}\right)$ for 1.5 hours, and the excess resin was sanded off. Tension tests of the bond strength were conducted by coating the 
Metal Fowder: carri. ar. arcon gas

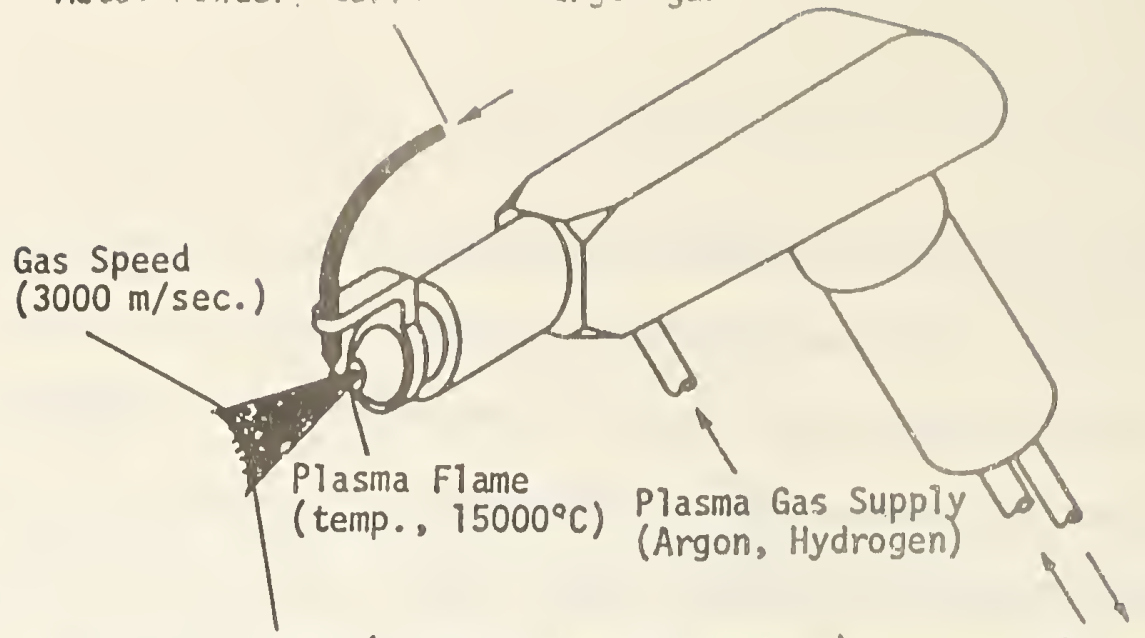

Metal particles (grain size: $0.05-0.1 \mathrm{~mm}$ ) are fused. Particle velocity, about $600 \mathrm{~m} / \mathrm{sec}$.

Figure 1. Schematic drawing of the arc plasma spray gun.

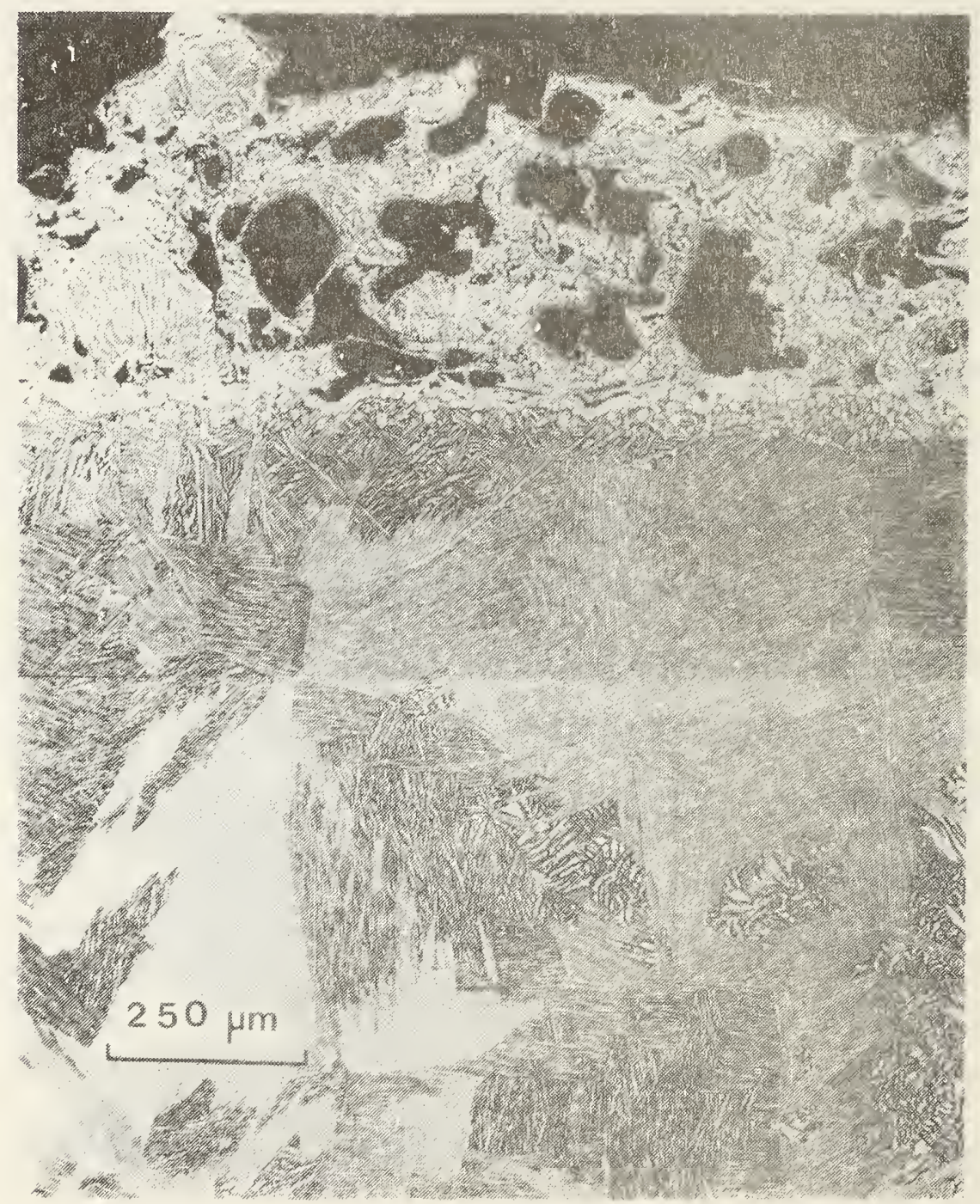

Figure 2. Light micrograph or APS Ti-6Al-4V coating on Ti-6Al-4V after sintering at $982^{\circ} \mathrm{C}\left(1800^{\circ} \mathrm{F}\right)$. 
flat ends of cylindrical rods and filling and bonding together with the resin. The lap shear and tension specimens were tested with a Model TTC Instron Testing Machine with a $45 \mathrm{KN}(10,000 \mathrm{lb})$ capacity and a cross head speed of $0.25 \mathrm{~mm}(0.01 \mathrm{in}$.). Corrosion-fatigue tests of coated cylindrical specimens were conducted in fully reversible torsion in a saline solution (Hanks' solution) environment. The applied shear strain amplitude was \pm 0.010 to 0.022 and the cyclic twist was at a frequency of $1 \mathrm{~Hz}$. The solution was held at a temperature of $37^{\circ} \mathrm{C}$ and had a $\mathrm{pH}$ of 7.4 . The open circuit potential in volts was measured versus a standard calomel electrode (S.C.E.) and recorded throughout the test. This potential was at a more positive value when the specimen was at rest and after the specimen broke. This provided another method, in addition to the cycle counts, for determining the number of cycles to failure. The open circuit potential is more negative during cyclic twist due to breaking and straining of the surface oxide film.

\section{Results and Discussion}

The cross sections of specimens showing the microstructures of the substrate and coating after heat treating at $982^{\circ} \mathrm{C}\left(1800^{\circ} \mathrm{F}\right)$ and at $899^{\circ} \mathrm{C}\left(1650^{\circ} \mathrm{F}\right)$ are shown in Figures 2 and 3 , respectively. The porosity probably is interconnecting although it may not appear to be so in this cross section. The specimen in figure 2 was sintered above the beta transformation temperature $980^{\circ} \mathrm{C}\left(1796^{\circ} \mathrm{F}\right)$ as is evident from the ordered "needle or platlet" structure. The material in figure 3 was sintered below the beta transus, and the needle or lathe structure is not present. Sintering above the beta transus has deliterious effects on the mechanical properties, and sintering at $982^{\circ} \mathrm{C}$ $\left(1800^{\circ} \mathrm{F}\right)$ was discontinued.

The surface structure and porosity are shown in Figures 4 and 5 . The size of the pores and the percent of porosity can be controlled by controlling the size of the powder which is sprayed and other parameters of the process. Figure 4 is a photomicrograph of a Ti sponge coating sprayed on a Ti-6Al-4V substrate. Figure 5 is 
a Ti-6AT-4V coating sprayed on a Ti-6AT-4V substrate. There was no great difference in the physical appearance of the coating.

The results ${ }^{2}$ of the lap shear tests of the Ti sponge top coating gave a strength of $8.36 \mathrm{MPa}(1213 \mathrm{psi})$ in the unsintered condition and $7.47 \mathrm{MPa}(1084 \mathrm{psi})$ after sintering. The strength of the Ti-6Al-4V top coat after sintering was $10.66 \mathrm{MPa}(1546 \mathrm{psi})$. The strength of the Ti-6AT-4V alloy is higher than that of pure titanium in either solid or porous form. The tensile strength of the Ti sponge coating was $8.54 \mathrm{MPa}(1238 \mathrm{ps} i$ ) in the unsintered condition and $19.36 \mathrm{MPa}(2808 \mathrm{psi})$ in the sintered condition. The tensile strength of the Ti-6AT-4V sintered coating was $28.45 \mathrm{MPa}(4127 \mathrm{psi})$.

More studies are needed regarding the effects of sintering on these coatings. There is the possibility that the oxygen which is inadvertently introduced during the production of the coating diffuses into the titanium. This would provide a strengthening effect in tension but the fatigue strength, especially torsion fatigue would be reduced.

Figure 6 shows the substrate interface and porous coating. Microhardness measurements were made across this type of section for both the unsintered and the sintered material. Some of these data are summarized in Table 1. Comparison of data in row $A$ with that in row $B$ for the $T i$ coating and the Ti-6AT-4V coating shows that after sintering, a trend exists for an increase in hardness in the material. Hardness measurements made in areas of the coating other than the spherical particles, gave hardness values exceeding 900. These measurements were limited, and these data are not shown in the table. The confidence level of the values listed in the table could be raised by increasing the number of measurements.

Data on the corrosion-fatigue life are given in Table 2. The data presented here are from tests using an applied shear strain amplitude of \pm 0.010 . Ten other corrosion fatigue tests were conducted in the shear strain range of \pm 0.004 to \pm 0.022 . The data shown in Table 2 can be used to 


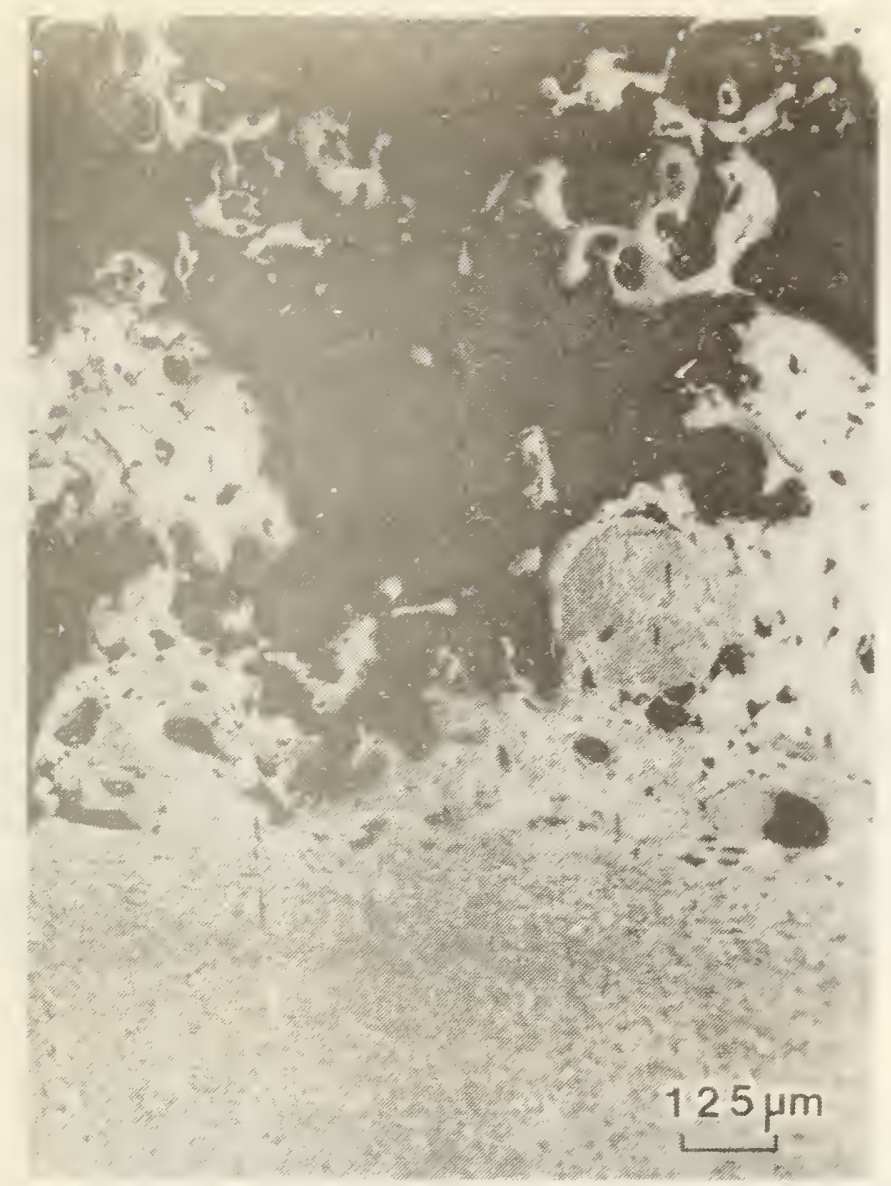

Figure 3. Light Micrograph of an APS Ti-6Al-4V coating on Ti-6A $1-4 \mathrm{~V}$ after sintering at $900^{\circ} \mathrm{C}\left(1650^{\circ} \mathrm{F}\right)$.

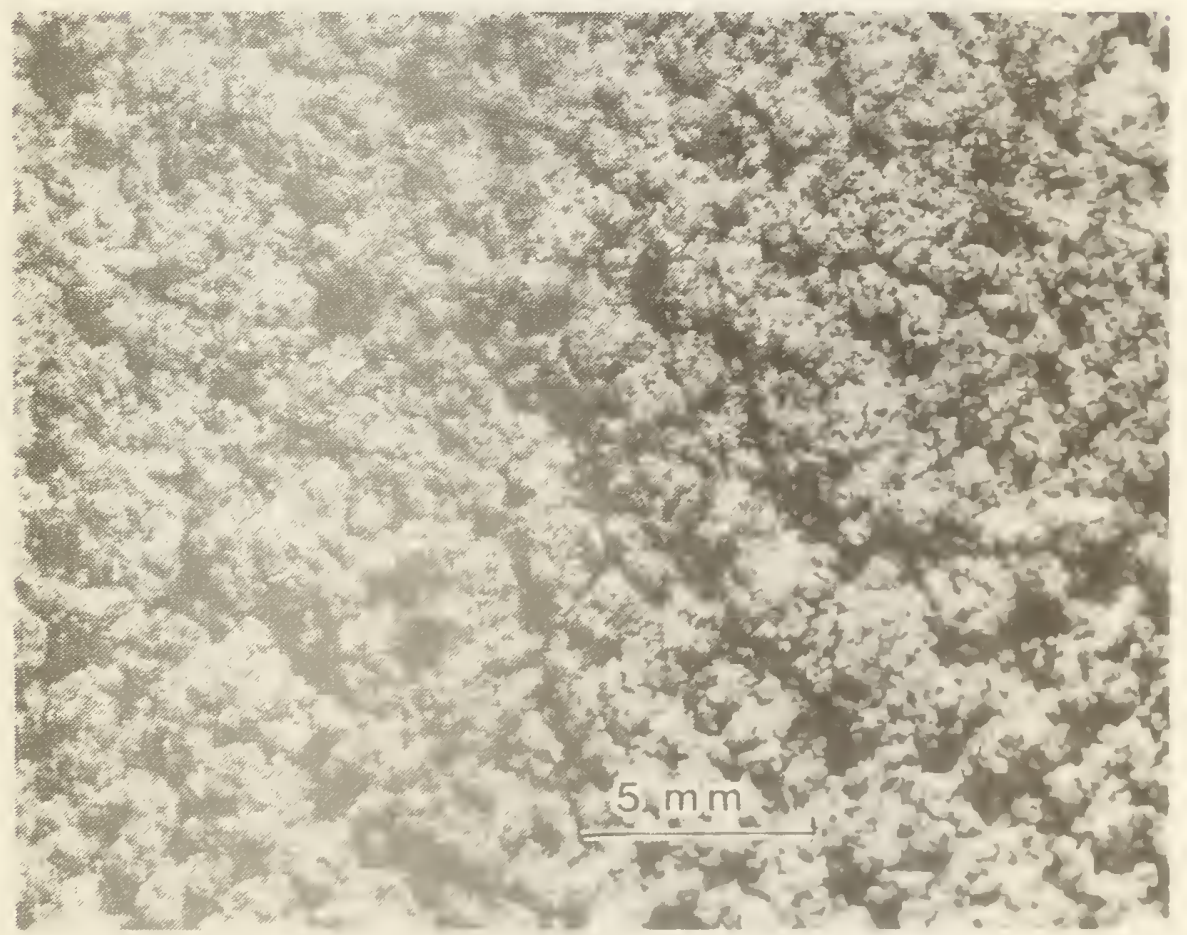

Figure 4. Light Micrograph showing surface morphology of an APS Ti sponge coating on a Ti-6AT-4V substrate. 


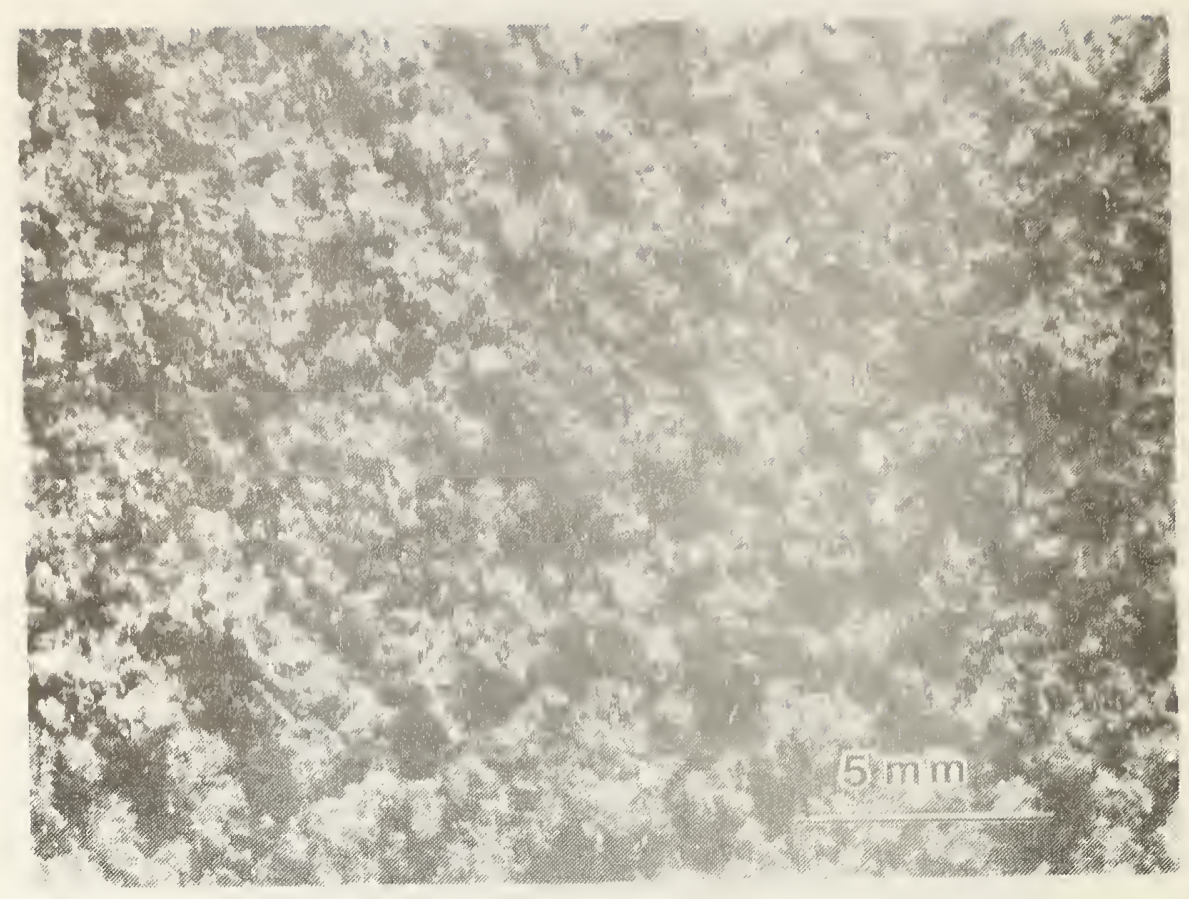

Figure 5. Light micrograph showing surface morphology of an APS Ti-6AT-4V coating on a Ti-6AT-4V substrate.

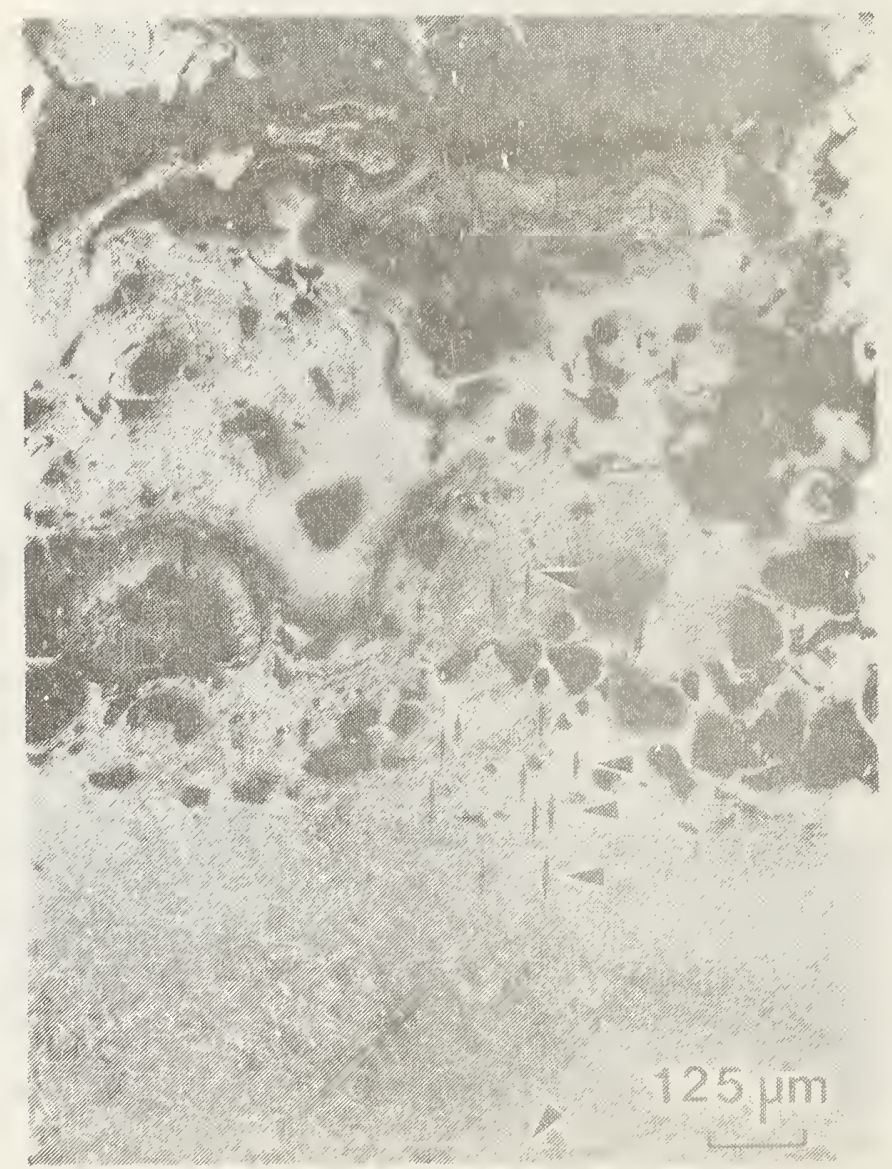

Figure 6. Light micrograph of APS Ti-6AT-4V coating on Ti-6AT-4V after sintering at $870^{\circ} \mathrm{C}\left(1600^{\circ} \mathrm{F}\right)$ and making hardness measurements (see arrows). 
Type of Coating on

Ti-6Al-4V

and Treatment
Spherical Particles Interface within coating

$H_{100}{ }^{a}\left(S_{0} D_{0}\right)^{b}$
Substrate .004" Substrate from interface

$H_{100}$ (S.D.) HK $H_{100}$ (S.D.)

(A) -20+40mesh

Ti-6Al-4V,

$626(7)$

$569 \quad(87)$

$445 \quad(56)$

380

(22)

sintered, $870^{\circ} \mathrm{C} / 16 \mathrm{hrs}$

(B) $-20+40$ mesh

Ti-6Al-4V, unsintered

$431 \quad$ (134)

$530 \quad(116)$

$336 \quad(12)$

348

(8)

(A) $\mathrm{Ti}$ sponge,

sintered, $870^{\circ} \mathrm{C} / 16 \mathrm{hrs}$

$599 \quad(72)$

$617 \quad(65)$

501 (194)

349

(24)

(B) Ti sponge, uns intered

$350 \quad(33)$

484 (149)

$347 \quad(22)$

330

a Mean $H_{1} K_{100}$ value, 4 to 8 measurements

b (S.D.), Standard Deviation 
Table 2. Corrosion-Fatigue Test Results at an Applied Shear Strain Amplitude of \pm 0.010

Specimen* and Treatment

M - Machined and polished, unsintered

F - Grit blasted, unsintered

G - Grit blasted, unsintered

$L-T i-6 A T-4 V$ coating, unsintered

$J$ - Ti-6AT-4V coating, sintered, $900^{\circ} \mathrm{C}\left(1650^{\circ} \mathrm{F}\right)$

K - Ti-6AT-4V coating, sintered, $900^{\circ} \mathrm{C}\left(1650^{\circ} \mathrm{F}\right)$

D - Ti sponge top coat, unsintered

C - Ti sponge top coat, sintered, $870^{\circ} \mathrm{C}\left(1600^{\circ} \mathrm{F}\right)$

$B$ - Ti-6AT-4V top coat, unsintered

A - Ti-6Al-4V top coat, sintered $870^{\circ} \mathrm{C}\left(1600^{\circ} \mathrm{F}\right)$

E - Ti-6Al-4V top coat, sintered $982^{\circ} \mathrm{C}\left(1800^{\circ} \mathrm{F}\right)$

$\mathrm{H}-\mathrm{Ti}-6 \mathrm{Al}-4 \mathrm{~V}$, uncoated,grit blasted, sintered, $982^{\circ} \mathrm{C}\left(1800^{\circ} \mathrm{F}\right)$

I - Ti-6Al-4V,uncoated,grit blasted, sintered, $982^{\circ} \mathrm{C}\left(1800^{\circ} \mathrm{F}\right)$
Number of Cycles to Fallure

$>10^{6 * *}$

$>106 * *$

$>10^{6 * *}$

$>10^{6 * *}$

$9.3 \times 10^{5}$

$9.4 \times 10^{5}$

$>10^{6 * *}$

$2.2 \times 10^{5}$

$4.8 \times 10^{5}$

$7.5 \times 10^{4}$

$9.8 \times 10^{3}$

$4.3 \times 10^{3}$

$4.4 \times 10^{4}$

*Specimen substrate material was ELI Ti-6Al-4V in an annealed condition.

** Tests were stopped after exceeding $10^{6}$ cycles, but these specimens did not fail. 
compare effects of surface treatment, sintering and sintering temperature. It is evident from this table that sintering at a temperature above the beta transus temperature decreases the corrosion-fatigue life either with the coating or in the grit blasted condition. It can be expected that grit blasting results in a compressive stress on the surface which has a beneficial effect on the fatigue strength.

The specimens are designated by letters $A$ through $M$ in Table 2. Specimens sintered to $982^{\circ} \mathrm{C}\left(1800^{\circ} \mathrm{F}\right)$ had a low fatigue $7 \mathrm{ife}$. data from specimens C, A, J indicate that sintering at the lower temperatures also adversely affected the corrosion-fatigue life but to a lesser degree than sintering above the beta transus. The loss in fatigue strength for these specimens was not due to the the microstructural transformations but probably to the diffusion of oxygen into the material. The control material, specimen $M$, compares equally with the grit blasted material with no coating and with the coated material which is unsintered. These test data show that sintering adversely affects the corrosion-fatigue life of the material. 
Summary

Porous coatings of $\mathrm{Ti}$ and $\mathrm{Ti}-6 \mathrm{Al}-4 \mathrm{~V}$ were applied to $\mathrm{Ti}-6 \mathrm{Al}-4 \mathrm{~V}$ substrates using the technique of arc plasma spraying. Microstructural analyses and microhardness measurements were made on the coated specimens after sintering at high temperatures and after mechanical testing. Mechanical tests were conducted to measure shear strength, tensile strength and corrosion fatigue life. The following conclusions may be drawn from this investigation.

1. Arc plasma spraying can be used to apply porous coatings of either titanium sponge or $T i-6 \mathrm{~A} T-4 \mathrm{~V}$ to $\mathrm{Ti}-6 \mathrm{AT}-4 \mathrm{~V}$ substrates.

2. Grit blasting can result in some imbedded particles which do not wash out, and this whould be minimized. Grit blasting appears to have no detrimental effect on the fatigue strength.

3. The strength of the interface bond formed between the coating and the substrate is high. Failure in lap shear tests always occurred within the coating.

4. Parameters of the coating process can be varied to give a coating with either a large or a small pore size or to give a coating having a graduated pore size.

5. Control of plasma spraying techniques and subsequent heat treating are important to prevent oxidation and also to prevent microstructural changes in the substrate metal.

6. Microhardness measurements increase within the material after sintering which is indicative of oxygen diffusion into the material.

7. Application of the porous coating has not been shown to reduce the corrosion-fatigue 1 ife of the substrate if the coated specimen is not sintered. Sintering can lower the fatigue resistance. 


\section{References}

1. Hahn, H, and Palich, W., Preliminary Evaluation of Porous Metal Surfaced Titanium for Orthopedic Implants, J. Biomed. Mater. Res., 4, 571-577, 1970.

2. Hahn, H., Bone Implant, U. S. Patent $3605123,1971$.

3. Hahn, H., Rowe, R., Lare, P. J., Fraker, A. C. and Ordway, F., ASTM Spec. Tech. Pub. 859, Symposium on Corrosion and Degradation of Implant Materials, Eds. A. C. Fraker and C. D. Griffin, to be published, 1985.

4. Sutter, F., Schroeder, A. and Straumann, F., Engineering and Design Aspects of the I.T.I. Hollow Basket Implants, J. Oral Implantology, Vol. X, No. 4, 1983. 


\section{Acknowledgements}

The receipt of materials and specimens from the following individuals and companies is gratefully acknowledged; Larry Gustavson, Howmedica, Inc., Rutherford, NJ,; Todd Smith, De Puy Mfg. Co., Inc., Warsaw, IN 46580; Henry Hahn, Artech Corp., Falls Church, VA. 
U.S. OEPT. OF COMM.

BIBLIOGRAPHIC DATA

SHEET (See in structions)

4. TITLE AND SUBTITLE
1. PUBLICATION OR REPORT NO.

NBSIR $-85-3166$

\section{Studies of Porous Metal Coated Surgical Implants}

5. AUTHOR(S) A. C. Fraker; A. W. Ruff; A. C. Van Orden; H. Hahn; A. J. Bailey and C. D. 01 son

6. PERFORMING ORGANIZATION (If joint or other than NBS, see instructions)

7. ContracVGrant No.

NATIONAL BUREAU OF STANDARDS

DEPARTMENT OF COMMERCE

WASHINGTON, D.C. 20234

8. Type of Report \& Period Covered

9. SPONSORING ORGANIZATION NAME AND COMPLETE ADDRESS (Street, City, Stote, ZIP)

Document describes a computer program; SF-185, FIPS Software Summary, is attached.

11. ABSTRACT (A 200-word or less factual summary of most significant information. If document includes a significant bibliography or literature survey, mention it here)

The material in this report deals with the subject of metal porous coated surgical implants which are used primarily for orthopedic applications. The report is presented in three parts. The first part gives a brief history of the development of various types of metal porous coated implants and discusses the need for improved fixation of orthopedic devices which led to the investigation of porous coatings for bony ingrowth attachment. The second part of the report contains experimental data on the corrosion behavior of sintered spheres of $\mathrm{Co}-\mathrm{Cr}-\mathrm{Mo}$ and analysis of surface films after exposure to saline solution. The third part reports on a corrosion-fatigue study of arc plasma sprayed porous $\mathrm{Ti}$ and $\mathrm{Ti}-6 \mathrm{Al}-4 \mathrm{~V}$ coatings. The porous coatings on the materials studied did not adversely affect the corrosion or mechanical properties of the material. Changes in processing, contamination, etc. could have detrimental effects on the chemical and mechanical behavior of the materials.

12. KEY WORDS (Six to twelve entries; alphabetical order; capitalize only proper names; and separate key words by semicolons) cobalt-chromium-molybdenum alloy; corrosion; fatigue; metal porous coating; surgical implants; titanium-6 aluminum-4 vanadium alloy

\section{AVAILABILITY}

[x] Unlimited

D For Official Distribution. Do Not Release to NTIS Order From Superintendent of Documents, U.S. Government Printing Office, Washington, D.C.
20402 . 


